\title{
3. Chinese corporate debt and credit misallocation
}

\author{
Ninghua Zhong, Mi Xie and Zhikuo Liư
}

\section{Introduction}

After the 2008-09 Global Financial Crisis (GFC), the efficiency of credit allocation in China’s financial system dropped significantly. According to Figure 3.1, it took about RMB1 (US\$0.14) of new credit to create a unit of gross domestic product (GDP) by 2008, but this credit intensity has since risen sharply and recently reached more than RMB3 (US\$0.48).

Meanwhile, China's broad measure of money supply (M2) surged after 2008, from RMB47 trillion (US\$6.8 trillion) in 2008 to RMB155 trillion (US\$23.3 trillion) in 2016 (Figure 3.2). That is, in eight years, M2 increased by more than RMB100 trillion (US\$16.6 trillion). Recently, China's M2 has exceeded US\$20 trillion, surpassing the largest economies in the world, including the United States, in absolute terms. In addition, the ratio of M2 to GDP in China has reached more than 200 per cent.

Combined, these data indicate that although the total amount of credit and financial resources is skyrocketing, the efficiency of their allocation is significantly deteriorating. In other words, large amounts of money have been allocated to inefficient areas or even wasted, resulting in a phenomenon called 'finance does not support entities', which is heatedly debated in mainland China.

With the declining efficiency of credit allocation, the overall rate of leveraging in China is on the rise. According to estimations by the Chinese Academy of Social Sciences and various other organisations, ${ }^{2}$ China's total debt had reached RMB168 trillion (US\$27 trillion) and the ratio of total debt to GDP was up to 249 per cent by the end of 2015. This level was in line with that of some developed countries, including the United States, the United Kingdom and the euro area, but was much

1 We thank Wing Thye Woo and other seminar participants at the Asian Economic Panel for valuable comments and suggestions. Ninghua Zhong acknowledges financial support from the National High-Level Talents Special Support Program (Young Top-Notch Talent Program), the Fok Ying-Tong Education Foundation of China (Grant No. 161081), the National Social Science Foundation of China (Grant No. 13\&ZD015) and the StartUp Research Grant of Tongji University (Grant No. 180144). Zhikuo Liu acknowledges financial support from the National Natural Science Foundation of China (Grant No. 71503159) and the Program for Innovative Research Team of Shanghai University of Finance and Economics.

2 See the briefing meeting held by the Information Department of the State Council: www.toutiao.com/ i6296377658741621249/; and the report in the Financial Times: www.ftchinese.com/story/001067266?full=y. 
higher than that of developing countries such as Brazil (146 per cent) and India (128 per cent). It is estimated that this ratio is still currently above 250 per centthat is, total debt exceeds RMB200 trillion (US\$30 trillion) (Sohu Finance and Economics 2017).

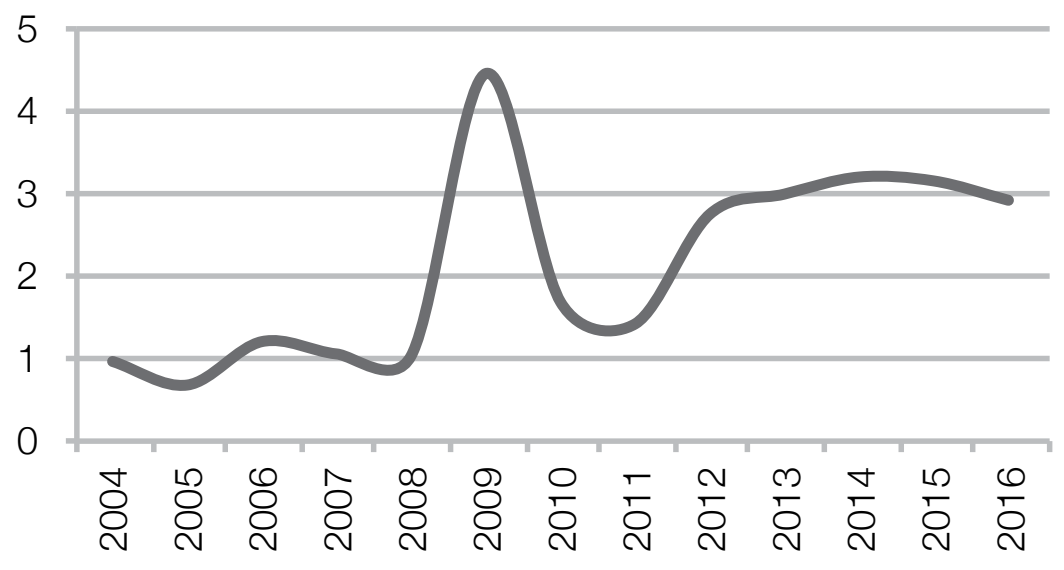

New credit per unit of additional GDP

Figure 3.1 Credit intensity (new credit/additional GDP) rising further Sources: CEIC Global Economic Database and NBS.

\section{M2 and M2/GDP (2006-2016)}

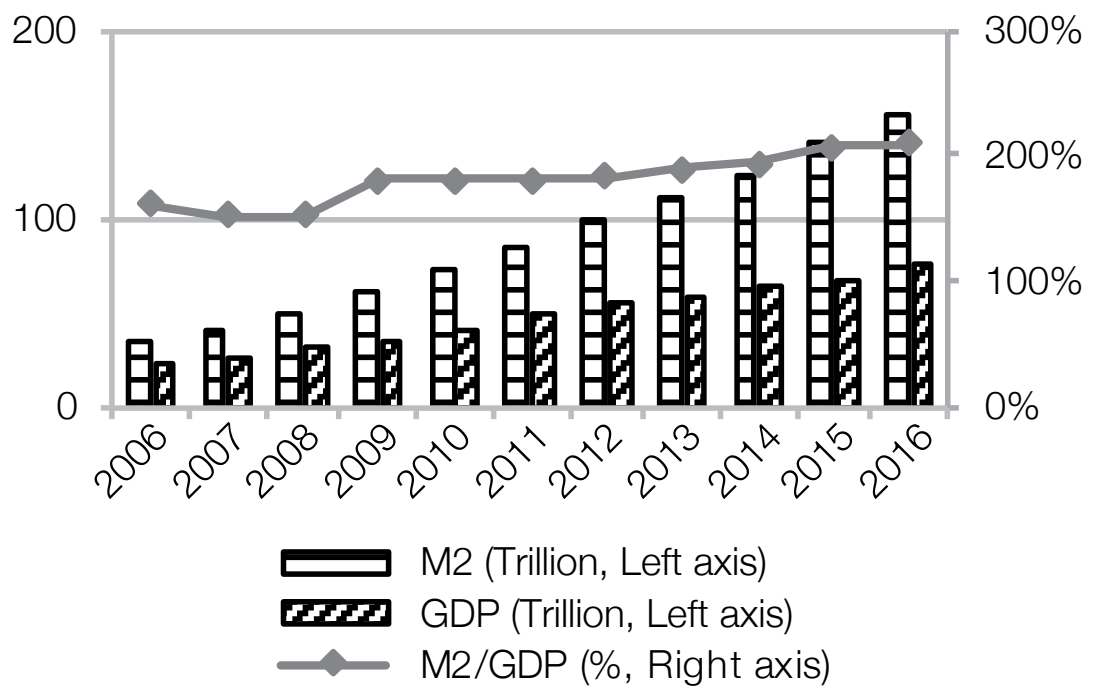

Figure 3.2 Funding supply surges: increasing M2 and M2/GDP Sources: CEIC Global Economic Database and NBS. 
Intriguingly, against the soaring trend of China's corporate debt, many Chinese small and medium-sized enterprises (SMEs), as well as private firms, have found it increasingly difficult to obtain loans from the formal financial sector. On the other hand, the overall economy urgently needs to transform towards being innovationdriven. Thus, more financial support is needed, and it is therefore argued that China should continue to use leverage.

Considering these factors, it is difficult to conclude whether China should continue leveraging. In fact, for a complicated economy such as China's, any general conclusion could be biased and any unified policies and measurements may be inefficient. Perhaps, rather than discussing the overall 'optimal debt ratio' for the Chinese economy, we should first pin down some basic facts, such as: where is the leverage across different sectors, industries, regions, ownership types and periods? This is the first question we want to answer in this chapter.

Several recent reports have pointed out that nonfinancial enterprises have the highest debt across different sectors in China (for example, enterprise, residential and government), and that debt has risen rapidly since 2008. During the period 2004-08, such debt accounted for less than 100 per cent of China's GDP (Sina Finance 2017), whereas it reached 105.4 per cent of GDP in 2010, surpassing that of all other major countries (China News 2012). It continued to soar in the following years and reached 163 per cent in June 2015 (Caixin 2016). Moreover, according to estimates by Standard \& Poor's (2014), by the end of 2013, the total debt of nonfinancial enterprises in China was US\$14.2 trillion, exceeding that in the United States (US\$13.1 trillion). They further predicted that, by the end of 2018, China's corporate debt would account for more than one-third of total corporate debt worldwide.

This chapter also examines the changes in corporate leveraging in China, mainly using data from China's industrial enterprises that were above designated scale during the period 1998-2013, ${ }^{3}$ which come from the Annual Survey of Industrial Enterprises conducted by the National Bureau of Statistics of China (NBS various years). We first analyse the debt ratio (that is, total liabilities/total assets) of nearly 4 million observations in this dataset. As can be seen from Figure 3.3, the simple average and median of debt ratio decreased from 65 per cent in 1998 to 51 per cent in 2013, representing a decline of 14 percentage points in 15 years and an average decline of nearly 1 percentage point annually.

3 During the period 1998-2006, those enterprises designated as being above scale were the entire state-owned industrial sector and the non-state-owned enterprises with an annual operating income of RMB5 million (US\$0.68 million) or more. From the beginning of 2007, it excluded those whose annual operating income was less than RMB5 million even if they were SOEs. Furthermore, the standard has been raised from an annual operating income of RMB5 million to RMB20 million (US\$3.17 million) since 2011. 
Furthermore, breaking down total debt into short-term debt (matured within one year) and long-term debt, we find that the ratio of average short-term debt to total assets decreased from 55 per cent in 1998 to 47 per cent in 2013 (see Figure 3.4), and the ratio of average long-term debt decreased from 11 per cent in 1998 to 6 per cent in 2013 (see Figure 3.5). That is, the short-term debt ratio declined by 8 percentage points during the sample period, while the long-term debt ratio only declined by 5 percentage points, so the short-term debt ratio contributes more to the decline in total debt ratio. However, given the very low initial level of long-term liabilities, it takes a much larger decrease indeed. It is worth noting that the median long-term debt ratio was zero for most years, indicating that more than half of the sampled enterprises were unable to obtain any long-term debt.

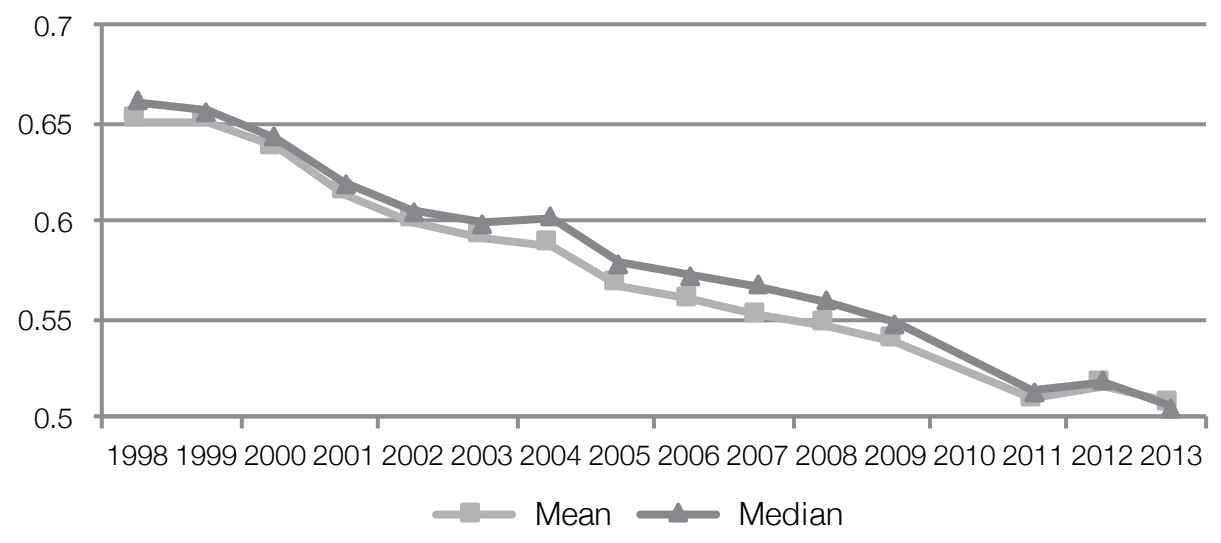

Figure 3.3 Average debt ratio of China's unlisted industrial enterprises Source: NBS (various years).

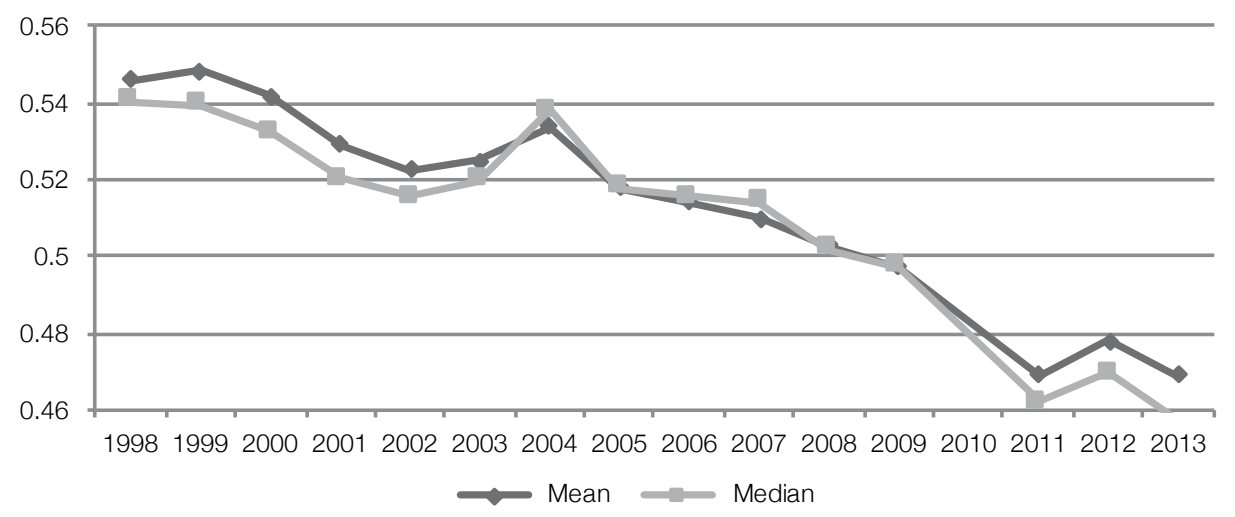

Figure 3.4 Short-term debt ratio of China's unlisted industrial enterprises Source: NBS (various years). 


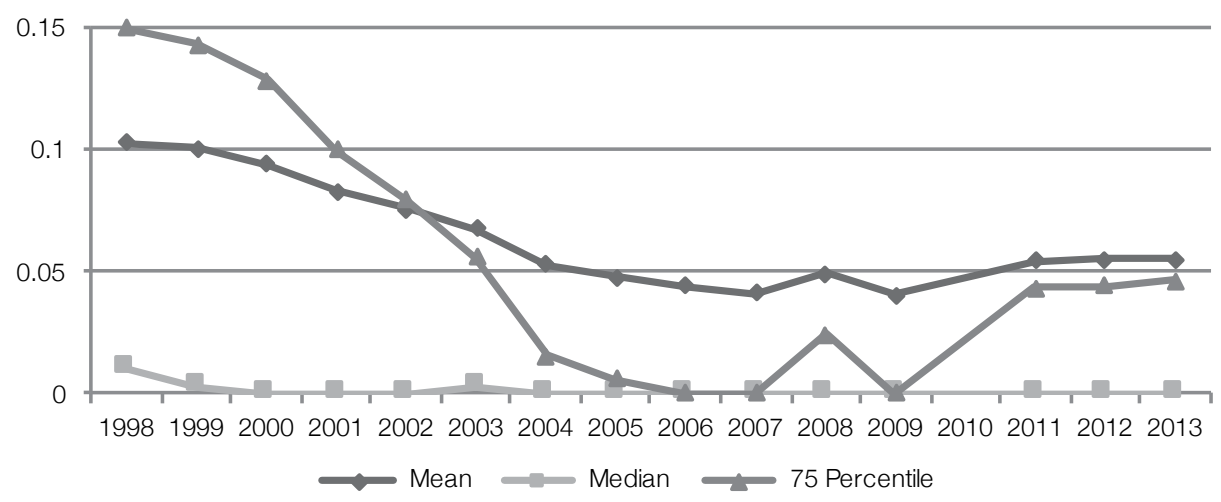

Figure 3.5 Long-term debt ratio of China's unlisted industrial enterprises Source: NBS (various years).

This declining trend is inconsistent with the rising corporate debt ratio that we have observed in the aggregate data. We thus deduce that it is a small sample of firms that have raised their leverage significantly. We thus divide the whole sample according to different standards and provide detailed statistical descriptions in section two. After elaborative examination, we summarise the following six facts.

- Fact 1: The longer a firm remains in the sample, the smaller is the decline in its debt ratio.

- Fact 2: The debt ratio of large enterprises decreased slightly, whereas that of SMEs dropped significantly.

- $\quad$ Fact 3: The decreasing range of the debt ratio of heavy industrial enterprises was generally much smaller than that of light industrial enterprises; and the average debt ratio of public utility enterprises was on the rise.

- $\quad$ Fact 4: The average debt ratio of enterprises in north-eastern and central China decreased the most-by more than 20 per cent-whereas the ratios of those enterprises in the developed eastern regions were quite stable.

- Fact 5: The average debt ratio of state-owned enterprises (SOEs) was always higher than that of private enterprises, which was, in turn, higher than that of foreign-funded enterprises. Among all types of enterprises, the average debt ratio of SOEs dropped the most. It is worth noting that the average debt ratio of longstanding SOEs was stable and rose after 2009.

- $\quad$ Fact 6: The average debt ratio of manufacturing enterprises listed on the Main Board was on the rise and surpassed that of unlisted companies after 2009.

Although these facts are simple statistical descriptions, they may provide an important basis for discussing the debt ratio in China and correct some existing mainstream views. First, in recent years, many media and institutional reports have focused on the record high debt ratios in China after the GFC, creating an idea 
that the debt ratio of Chinese enterprises is generally on the rise. In fact, our six facts show that the increase in debt ratios is sharply concentrated in thousands of enterprises, most of which are large, state-owned and listed companies.

The following statistics best emphasise the sharp concentration of Chinese corporate debt. The data for Chinese industrial enterprises include about 345,000 enterprises for 2013; those enterprises had debts totalling RMB49.1 trillion (US\$7.4 trillion). Nearly half of the total debt was held by the top 2,000 enterprises (RMB13.5 trillion; US\$2 trillion) and more than one-quarter was held by the top 500 enterprises (RMB23.5 trillion; US\$3.5 trillion). We also analysed the second dataset-that of Chinese listed firms — and obtained similar findings. According to our estimation, in 2015, the top 300 heavily indebted listed enterprises owed 82 per cent of all debt, amounting to RMB16 trillion (US\$2.4 trillion), and the top 50 enterprises owed 54 per cent of all debt, amounting to RMB11 trillion (US\$1.7 trillion).

Among them, PetroChina-China's largest oil and gas producer-was the most indebted listed company, owing RMB1 trillion (US\$150 billion) in 2015. It was followed by China State Construction Engineering Corporation, China Petroleum and Chemical Corporation, China Railway Construction Corporation, China Railway Group Limited and China Communications Construction Corporation (which was listed in 2012 and did not release data before 2011). In 2015, those five companies held total debts of more than RMB3 trillion (US\$450 billion). In addition, according to the 21st Century Business Herald, by the end of 2015, the total debt of the seven major coal enterprises in Shanxi exceeded RMB1.1 trillion (US\$180 billion). ${ }^{4}$

Thus, China's corporate debt issue is highly 'structural'. Most debts are held by a small fraction of companies, whereas the debt ratio in most companies is declining.

After establishing the basic facts, sections three and four of this chapter attempt to further explore the question of whether the changing debt ratio is supported by economic fundamentals using both firm-level (that is, microlevel) and aggregatelevel (that is, macrolevel) data. China is not an exception to the rule that the rapid growth of developing countries is usually accompanied by an increase in the debt of the enterprise sector. Therefore, we need more precise analysis to answer the question of whether the rising leverage of nonfinancial enterprises is supported by their fundamentals - because, in the past few decades, with the rapid marketisation process in China, some of the main characteristics of Chinese enterprises have changed significantly. For example, their profitability has improved significantly (see Figure 3.6). It is reasonable for an enterprise to borrow more money from outside based on its rising profitability, because its expected cash flows will allow it

4 See 'Shanxi's seven major coal enterprises' debts reach Y1.1 trillion, and rely on government's subsidies to pay wages', China mining, www.chinamining.org.cn/index.php?m=content\&c=index\&a=show\&catid=8\&id=17540. 
to repay more debt. ${ }^{5}$ Similarly, some enterprises in China-mainly large SOEshave experienced rapid capital deepening. In other words, they have more fixed assets. It is also reasonable for these enterprises to borrow more because they have more collateral; if they cannot repay, they can sell off fixed assets. Such increases in leveraging are backed by economic fundamentals.

On the other hand, there are some increases in leverage that are not supported by the economic fundamentals and are thus deeply concerning. For example, many recent discussions have referred to state-owned 'zombie' enterprises. According to Tan et al. (2016), in 2007, 12.1 per cent of Chinese industrial enterprises were zombie firms, and their proportions of assets and liabilities were 10.7 per cent and 13.4 per cent, respectively. ${ }^{6}$ It is estimated that these proportions rose significantly after the GFC. The profitability of these enterprises is extremely low or even negative; nevertheless, even with high debt, they could survive if given substantial loans through the banking system. Meanwhile, many more profitable private enterprises are unable to borrow from banks. Such a contrast leads to reasonable conjectures about increasing credit misallocation.

To explore this issue, in section three, we start by referring to the literature on Western capital structure and examining the changes in six important corporate characteristics that determine credit financing. We find that the average size of Chinese enterprises during the period 1998-2013 increased and their operational risk rose; the proportion of tangible assets (mainly fixed assets and inventories) has been declining and profitability has been continuously increasing. These changes are a result at the firm (micro) level of the transformation of China's economy towards being market-oriented. As competition in domestic and foreign product markets is becoming more intense, operational risks are increasing, while the profitability and scale of the surviving enterprises are becoming stronger and larger. In addition, market competition also forces enterprises to adopt a more competitive approach to production. Therefore, Chinese enterprises are constantly transforming to labour-intensive and light capitalisation, which is shown in the declining share of tangible assets.

These changing firm characteristics have varying influence on leveraging, therefore, we further refer to the standard regression models in the literature on Western capital structure to examine the relationships between these variables and the debt ratio. We find that, in the sample of private enterprises, the regression results are highly consistent with the Western literature; also, the changes in firm characteristics are consistent with changes in the debt ratio. For example: 1) the operating risk is negatively related to the debt ratio, so the rise in business risk may result in a decrease

5 On the other hand, enterprises with high profitability tend to rely less on external capital because they can generate enough cash flow.

6 The methodology for identifying zombie enterprises refers to the CHK approach presented in Caballero et al. (2008). 
of the debt ratio; 2) the tangible asset is the collateral of debt financing and is positively related to the debt ratio, the decline of which may lead to a decline in the debt ratio; and 3) the average profit margin of an enterprise is negatively related to the debt ratio - that is, the relationship between internal cash and external financing is an alternative. Therefore, the increase in profitability may also be the reason for the declining debt ratio. We hence draw a preliminary conclusion that the financing decisions of private enterprises are in line with the principles of marketisation.

In the sample of SOEs, however, except for the profit margin, other important firm characteristics are insignificant or even have an unexpected sign; we can hardly explain the change in the debt ratio of SOEs by the changes in firm characteristics. Apart from these analyses, we have also examined Chinese listed enterprises and found there were about 160 listed SOEs whose profits (earnings) before interest and tax were not enough to pay off interest. These enterprises could only keep borrowing to repay old debts; as a result, the debt 'snowballs'. This also indicates that the liabilities of some SOEs are too high, which eventually results in an excessive interest burden.

In section four, we use the aggregate-level (macro-level) data to provide further evidence of SOEs' overleveraging. We find that state-owned industrial enterprises as a whole have been increasing their leveraging since 2008 and their overall debt ratio rose from 58 per cent in 2008 to 62 per cent in 2016, whereas the private sector has been underaccelerating its deleveraging, with the overall average debt ratio falling from 58 per cent to 52 per cent. In other words, the private sector has been deleveraging for more than a decade. Moreover, recently, private industrial enterprises as a whole contributed nearly 40 per cent of the total profit of all industrial enterprises, while their liabilities accounted for only 20 per cent of the total. In contrast, state-owned industrial enterprises as a whole contributed less than 20 per cent of total profit, while their liabilities accounted for more than 40 per cent of the total. According to the Ministry of Finance, the total debt of the Chinese SOE sector has reached RMB100 trillion (US\$15.1 trillion), whereas the return on total assets is only 1.91 per cent. Therefore, we draw a preliminary conclusion that the leveraging of SOEs is not supported by the economic fundamentals, and there are some nonmarket factors that are driving up their leverage.

It is noteworthy that this conclusion is also consistent with another important phenomenon that emerged after the GFC: SOEs are heavily involved in shadow banking activities such as entrusted lending or loans (China Business Journal 2011). This suggests these enterprises do not have good investment opportunities themselves but are able to borrow large amounts of money from the financial system at a lower cost and then lend to others (for example, to the private sector) to obtain the interest spread, which also proves that the debt ratio of these SOEs is too high. 
This chapter differs significantly from the existing research on the capital structure of Chinese enterprises. Much of the research has been made by applying standard empirical tests from Western literature directly to Chinese enterprises and examining the power of the mainstream capital structure theories such as the 'pecking order theory' and 'trade-off theory' to impact Chinese corporate debt. For example, Chen (2004) finds that the capital structure of listed companies in China is not in line with the classic pecking order theory; rather, the order of their financing is retained earnings, equity financing and debt financing. Chen and Strange (2005) find that, unlike the expectation of the trade-off theory, Chinese listed companies do not show a stable optimal debt ratio. Newman et al. (2012) examined 1,539 privately owned SMEs in Zhejiang Province and found that firm size was positively correlated with the debt ratio, and there was a significant negative correlation between profitability and the debt ratio, which was consistent with the expectation of the pecking order theory. However, the relationship between the proportion of fixed assets and the debt ratio is not significant.

Other literature focuses on whether the main determinants of a firm's capital structure in a developed country can explain the capital structure of Chinese listed companies. For example, Huang and Song (2006) find that the correlations between the debt ratio of listed companies in China and firm size - and between the debt ratio and the proportion of fixed assets, profitability, nondebt tax shields and growth - are basically consistent with the empirical findings from developed countries; the main difference is that the share of long-term debt in Chinese companies is very low. Bhabra et al. (2008) examine the long-term debt ratio of listed companies in China and find that it is positively related to firm size and the proportion of tangible assets, but negatively correlated with profitability and growth.

In contrast to this research, $\mathrm{Li}$ et al. (2009) consider unique institutional factors in China, and their work is the most like our chapter. They study the capital structure of Chinese industrial firms during the period 2000-03. They find that stateowned and private enterprises have higher debt ratios than foreign-funded firms. In addition, in areas where the legal environment and the banking system are more developed, enterprises have lower total debt ratios.

The existing literature has focused on cross-sectional differences, whereas our chapter examines the changes in the time series - that is, trying to understand the significant changes in the debt ratio of Chinese enterprises in the context of China's overall economic transformation. As we will show later, during the relatively short sample period of 1998-2013, the debt ratio and key characteristics of Chinese enterprises have changed dramatically. Such dramatic changes only happen in rapidly transforming countries such as China. In mature economies such as the United States, both the financing and the main features of enterprises are much more stable; therefore, studies of the capital structure of Western enterprises naturally focus more on the cross-sectional differences. 
More importantly, the main purpose of this chapter is not to test or develop the Western capital structure theories, but to provide valuable analysis of and suggestions for whether and how to deleverage in China. For these complicated issues, our research is still relatively preliminary. Our results indicate that a complete answer should include at least two parts. First, the financing decisions of some enterprisesmainly private enterprises - are generally in line with the principle of marketisation. For these enterprises, adequate capital supply should be guaranteed so that the enterprises with fundamental support can borrow enough money. Second, there are many 'nonmarket-oriented' factors in the determinants of SOE debt. Thus, we should cease the transfusion of funds to inefficient firms as soon as possible and allocate new loans to the most efficient areas. Meanwhile, we suggest selling SOEs' stock assets to repay the stock liabilities. Considering the already very high total leverage ratio in China, the efficiency of the allocation of incremental funds would determine the potential for China's medium and long-term future economic growth.

\section{Where is the leverage?}

\section{The data}

The first firm-level dataset we examine comes from the Annual Survey of Industrial Enterprises conducted by the NBS from 1998 to 2013 (the data for 2010 is missing because of very poor quality), and the total original number of observations is $3,911,364$. We first examine the major accounting identities, ${ }^{7}$ requiring that the absolute value of [total liabilities + owner's equity - total assets] be less than 1 per cent of total assets, resulting in 82,783 observations being deleted. Second, we check the identity of the total debt, requiring that the absolute value of [total debt short-term debt - long-term debt] be less than 1 per cent of total assets, and delete 203,920 observations. Third, we delete 4,774 observations with current liabilities larger than total liabilities, 3,314 observations with long-term liabilities larger than total liabilities, and 30 observations with a negative main operating income. Thus, the new total number of observations is $3,616,543$.

In addition, some of the analyses in this chapter use the data for listed firms during the period 1998-2013 from the China Stock Market \& Accounting Research (CSMAR) Database. We delete the observations for nonindustrial enterprises, and exclude firms listed on the Small and Medium-Sized Enterprises Board and on the Growth Enterprise Market, which results in a total of 20,306 observations. We also do 1 per cent and 99 per cent Winsorization for each firm-level variable.

7 There is a large amount of missing data for 2008 and 2011-13 for short-term and long-term liabilities, so only non-missing samples are considered for the proofreading of debt identities. 


\section{Descriptive statistics on subsamples: Six facts}

In this section, we present six facts about changes in the debt ratio of Chinese enterprises in the subsamples sorted by various standards. These facts are fundamental to further exploring China’s leveraging issues.

\section{Fact 1: The longer a firm remains in the sample, the smaller is the decline in its debt ratio}

Fact 1 is the conclusion drawn by grouping the whole sample according to the number of consecutive years in which the enterprises exist in the database. We divide the enterprises into four groups, with the years of existence of the sample firms being 3, 7, 11 and 15 years. Figure 3.6 depicts the changes in the average debt ratio of these subsamples; the average debt ratio of the enterprises with continuous existence of more than three years was 67 per cent in 1998 and dropped to 48 per cent in 2008-a decrease of 19 percentage points. However, the average debt ratio of those firms that have existed for more than 15 years declined from 58 per cent to 54 per cent during this period—a decline of only 4 percentage points.

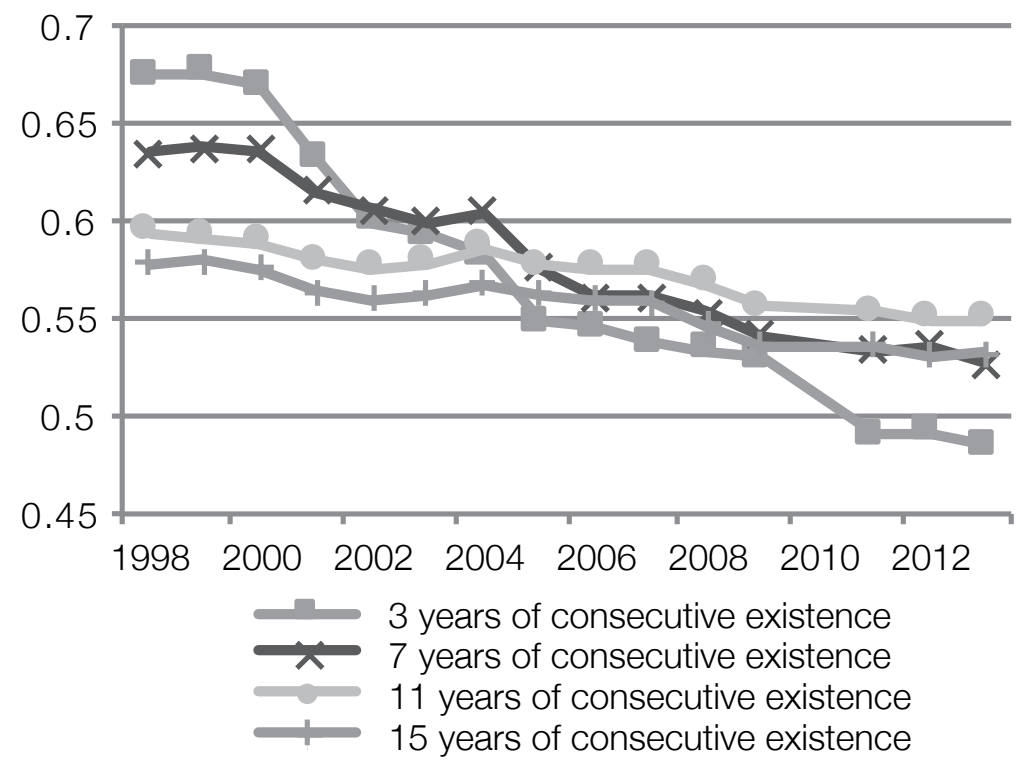

Figure 3.6 Debt ratio: Classified by years of existence

Source: NBS (various years). 


\section{Fact 2: The debt ratio of large enterprises decreased slightly, whereas that of SMEs dropped significantly}

We then classify the whole sample according to the size of the enterprises and conclude Fact 2. The division of large and medium-sized enterprises is based on the principle of the 'Interim Provisions on Standards for Small and Medium-sized Enterprises' formulated by the State Economic and Trade Commission, the State Development Planning Commission, the Ministry of Finance and the NBS in 2003. Accordingly, companies with fewer than 2,000 employees, annual revenue of less than RMB300 million (US $\$ 45$ million) or total assets of less than RMB400 million (US\$60 million) are defined as SMEs, while the remainder are defined as large enterprises. Figure 3.7 shows that the debt ratio of large enterprises decreased slightly, to 57 per cent, in 2013 from 61 per cent in 1998, whereas that of SMEs saw decreased sharply to 51 per cent in 2013 from 65 per cent in 1998. That is, the debt ratio of SMEs decreased significantly.

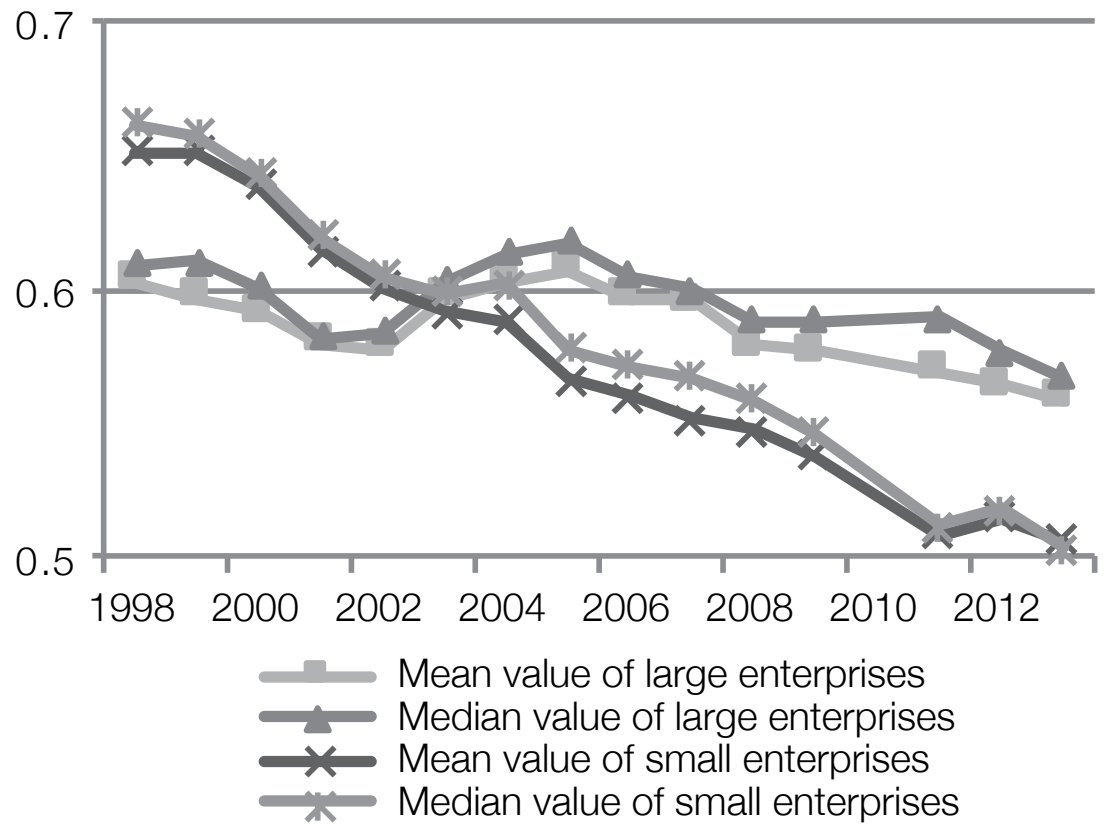

Figure 3.7 Debt ratio: Classified by enterprise scale Source: NBS (various years). 


\section{Fact 3: The decreasing range of the debt ratio in heavy industrial} enterprises was generally much smaller than that of light industrial ones; and the average debt ratio of public utility enterprises was on the rise

Fact 3 is the conclusion drawn by grouping the whole sample according to the industry of the enterprise. We divide the sample companies into 39 groups according to the two-digit industry classification number in the national economy. Because of the large number of industry groups, we do not report the results individually. In general, the debt ratio of heavy industrial enterprises saw a much smaller decline than that of light industrial enterprises. Figure 3.8 reports the debt ratio of several typical industries. For example, the debt ratio in the coal mining and washing industries fell to 58 per cent in 2013 from 61 per cent in 1998, and farm and sideline food-processing industries saw their debt ratio drop to 44 per cent in 2013 from 72 per cent in 1998 . The average debt ratio of public utility enterprises, however, was on the rise. For example, the average debt ratio of water production and supply enterprises rose to 55 per cent in 2013 from 40 per cent in 1998.

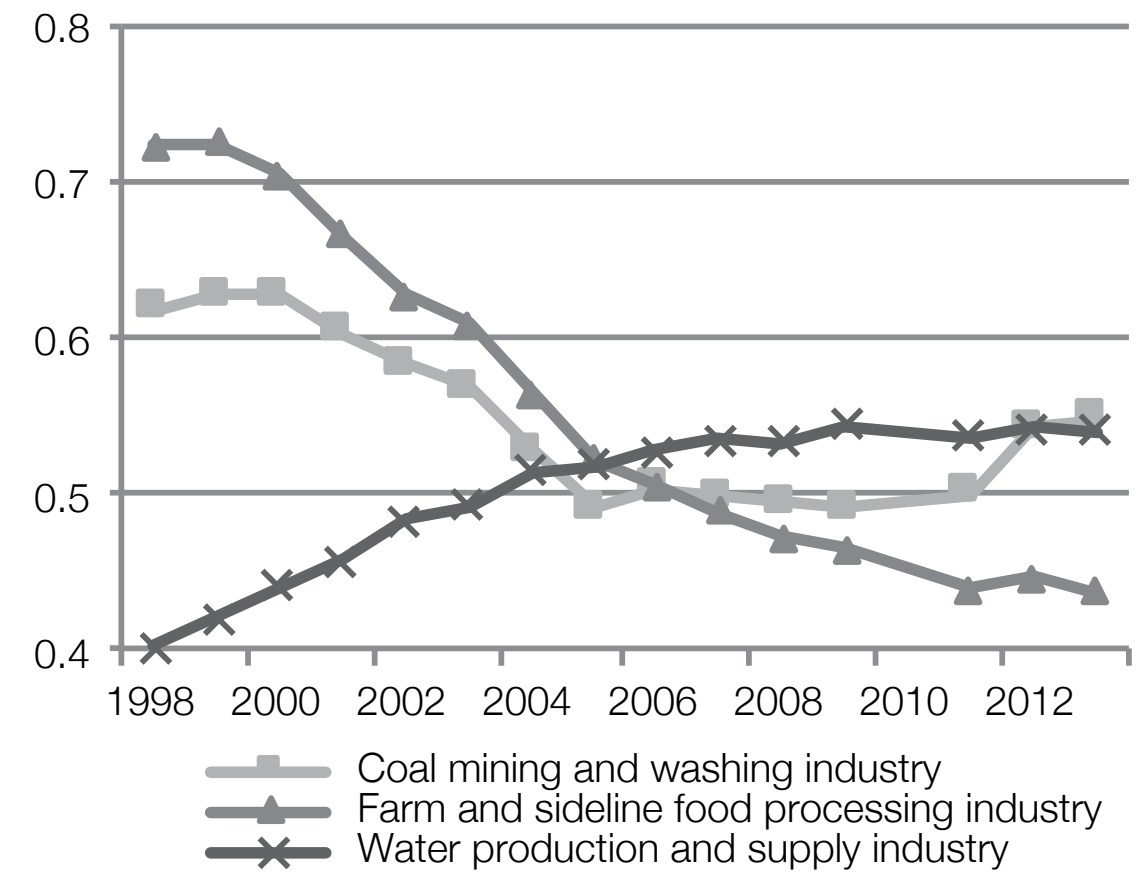

Figure 3.8 Debt ratio: Three typical industries

Source: NBS (various years). 
Fact 4: The average debt ratio of enterprises in north-eastern and central China decreased the most, by more than 20 percentage points, whereas that of enterprises in the developed eastern regions was stable

We conclude Fact 4 by dividing the whole sample according to the province in which the enterprise is located. The average debt ratios of enterprises in northeastern and central areas decreased by 20 percentage points, marking the maximum decline among different regions. Average debt ratios in the north-east, central and western regions were all about 69 per cent in 1998. The ratios declined to 45 per cent in the north-eastern and central regions by 2013 and to 55 per cent in the western region. The average debt ratio in the eastern region dropped by the smallest amount, to 55 per cent from 63 per cent in 1998 (see Figure 3.9). We have also examined the average debt ratio for each province and find six provinces stand out from the others. The average debt ratio in Beijing maintained a relatively stable trend; the ratio in Shanghai and Tianjin declined slightly while the average debt ratios in coastal districts such as Guangdong and Zhejiang increased slightly. Tibet was the only province with a significant increase (see Figure 3.10).

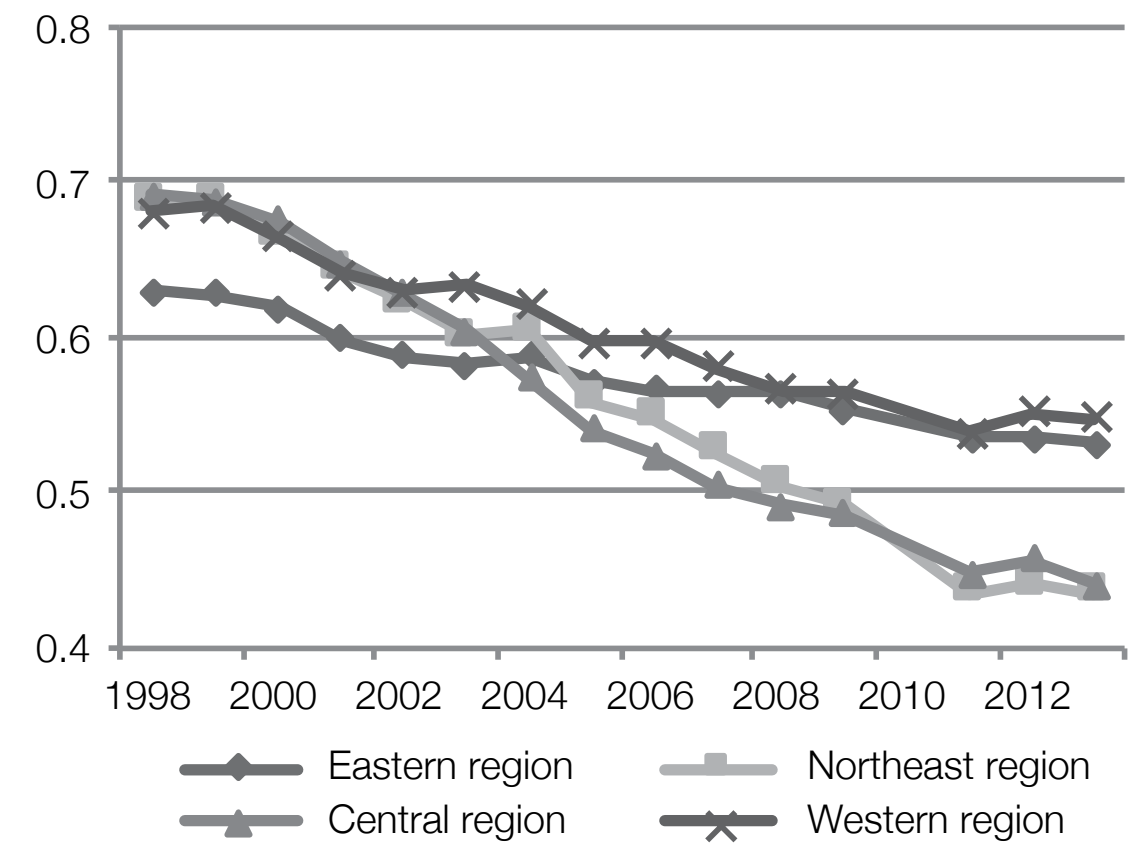

Figure 3.9 Debt ratio: Classified by enterprise region

Source: NBS (various years). 


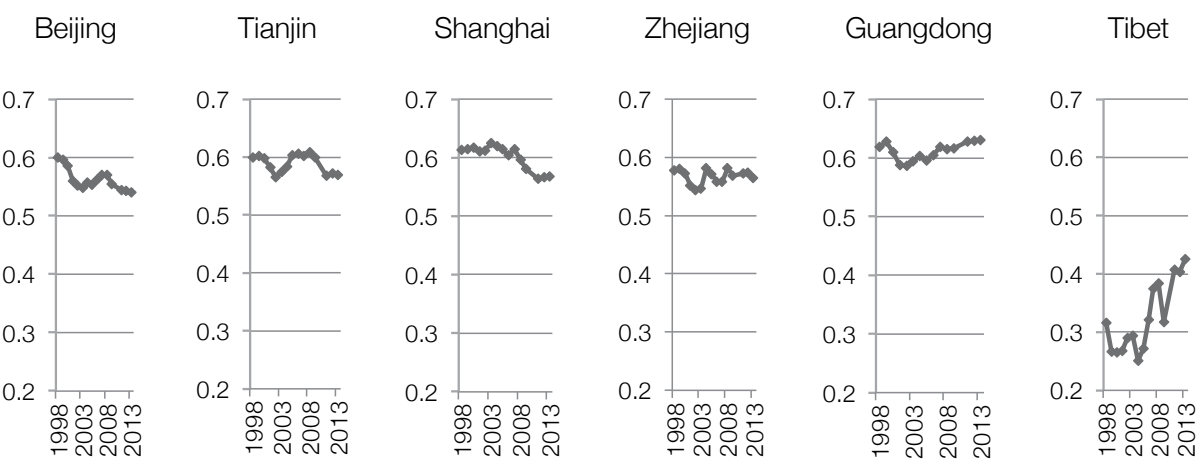

Figure 3.10 Debt ratio: Several special provinces Source: NBS (various years).

Fact 5: The average debt ratio of SOEs was always higher than that of private enterprises, which was, in turn, higher than that of foreign-funded enterprises. Among all types of enterprises, the average debt ratio of SOEs dropped the most. It is worth noting that the average debt ratio of SOEs in the sample that have existed for a long time was stable and rose after 2009

Fact 5 is the conclusion drawn by grouping the whole sample according to the registration type of enterprises and then examining their average debt ratio. ${ }^{8}$ During the period 1998-2013, the average debt ratio of SOEs dropped from 73 per cent to 62 per cent, compared with the decline from 58 per cent to 50 per cent for private enterprises and from 55 per cent to 50 per cent for foreign-funded enterprises (see Figure 3.11). The average debt ratio of SOEs has always been significantly higher than that in the private sector, while that in the private sector is generally higher than for foreign-funded enterprises. ${ }^{9}$ In addition, it is worth noting that it is becoming increasingly difficult for private enterprises to borrow money, and this trend seems to have begun earlier, in 2004, not after the GFC. ${ }^{10}$

8 The state-owned group includes SOEs, state-owned joint enterprises, state and collectively owned enterprises and wholly SOEs. The private sector includes privately owned enterprises, private partnership enterprises, private-limited enterprises and enterprises limited by shares. The foreign-funded sector includes joint ventures, cooperative enterprises, Hong Kong-owned, Macau-owned and Taiwan-owned enterprises and Hong Kong, Macau and Taiwan Investment Co. Ltd (if the investors from Hong Kong, Macau and Taiwan gain an investment ratio of more than 25 per cent), and Sino-foreign cooperative ventures, Sino-foreign joint ventures, wholly foreign-owned enterprises and foreign investment companies (if the proportion of foreign investment exceeds 25 per cent). The mixed sector includes collective enterprises, joint stock limited enterprises (domestic capital) and other enterprises.

9 Regarding this result, $\mathrm{Li}$ et al. (2009) provide a careful discussion based on the dataset from the 2000-03 industrial census.

10 Of course, the GFC significantly affected the private sector's exports and reduced its profitability, thereby enhancing the demand for external funds. This makes the issue of private financing constraints more prominent. 
Figure 3.11 also suggests that the decline in the debt ratio of SOEs was the largest during the period 1998-2013. However, a more interesting result about the correlation between ownership and firm capital structure is shown in Figure 3.12. By narrowing the sample to stable enterprises that existed in the database between 1998 and 2013 (that is, in existence over 15 years), we find the debt ratio of stable SOEs rose to 62 per cent in 2013 from 59 per cent in 1998, whereas the debt ratios of stable firms with other types of ownership were all declining.

Also noteworthy is the division within the state-owned sector in terms of access to loans. The average debt ratio of SOEs as a whole has decreased significantly, whereas only a small number among them has increased sharply. Based on this result, the reform of SOEs that was implemented in the past few decades seems to have broken the soft budgetary constraints of small and medium-sized SOEs. However, large SOEs still have easier access to capital, which could be the result of a policy—namely, 'managing the big, liberating the small'-taken by the Chinese central government since the late 1990s.

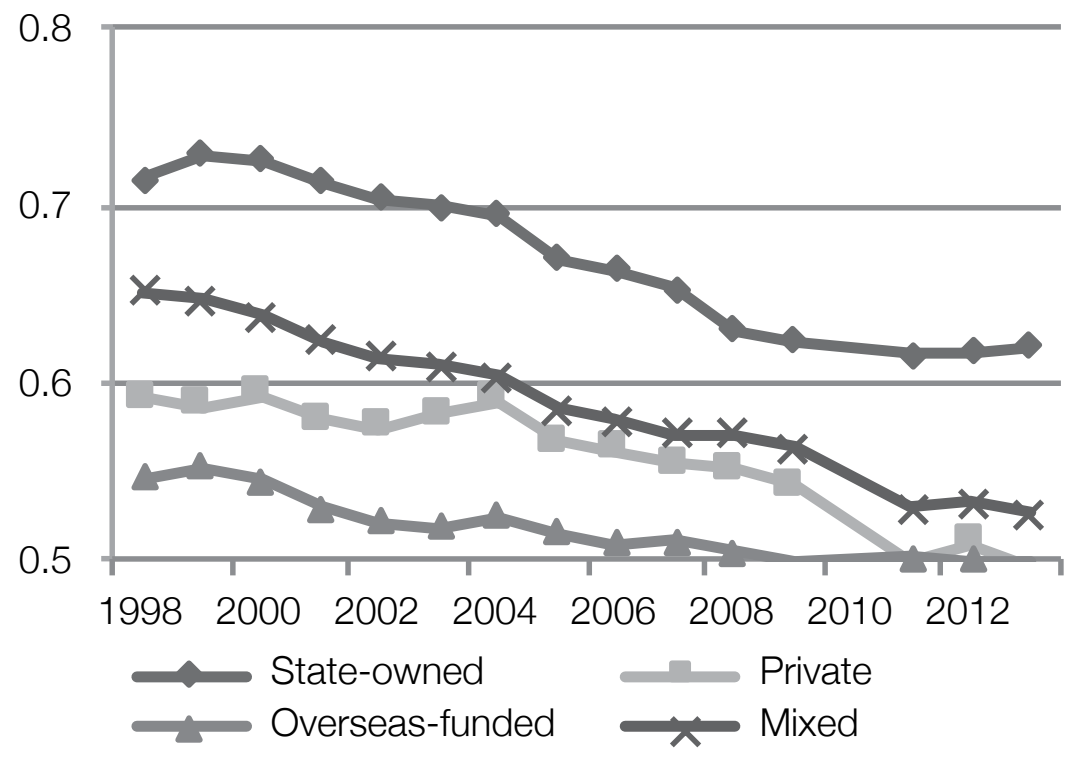

Figure 3.11 Debt ratio: Classified by ownership Source: NBS (various years). 


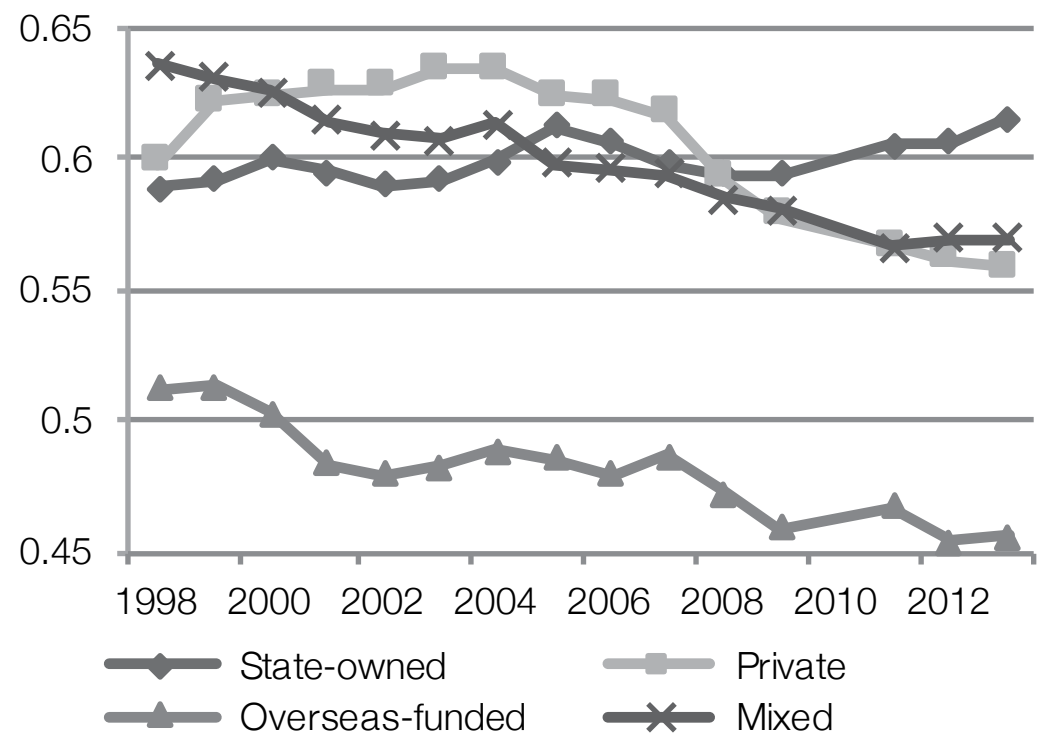

Figure 3.12 Debt ratio: Stable and persistent enterprises grouped according to ownership

Source: NBS (various years).

\section{Fact 6: The average debt ratio of listed manufacturing enterprises was on the rise and surpassed that of unlisted companies after 2009}

Finally, we put the debt ratios of listed and unlisted firms into one figure to conclude Fact 6. We use listed manufacturing companies that are traded on the main board of China's stock market, which is the only board that existed before 2004. The contrast is obvious for both the level and the trend of debt (see Figure 3.13). In 1998, the average debt ratio of listed manufacturing companies was 39 per cent. This amount is not unusual, because listed firms raise money through equity financing, and thus their proportion of debt financing is usually lower than that of unlisted firms. ${ }^{11}$ However, a more important finding is that whereas the average debt ratio of unlisted manufacturing companies is declining, that of listed manufacturing companies has continued to rise and has reached 55 per cent, exceeding that of unlisted manufacturing enterprises since 2009. ${ }^{12}$

11 Huang and Song (2006) compare the debt ratio of listed companies in China with that of other countries. They find that the total debt ratio and long-term debt ratio of listed companies in China are significantly lower, while the proportion of equity financing is significantly higher. They suggest one of the reasons for this is the high valuation of listed companies in China. Some related literature (such as Chen 2004) proposes that one of the characteristics of the financing in Chinese listed companies is that equity financing has priority over bond financing.

12 The rise of the debt ratio in Chinese listed companies during this period is mentioned in some of the literature, such as Huang and Song (2006). The explanation they give is the development of the bond market. Nevertheless, they (along with other researchers) do not dig deeply into the analysis of this phenomenon. 


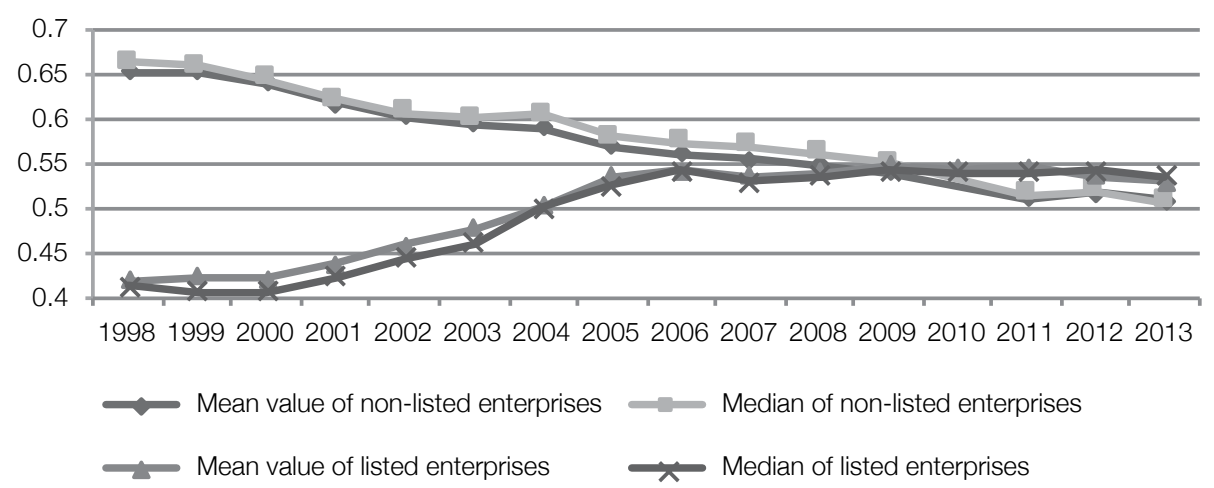

Figure 3.13 The opposing tendencies of debt ratios in listed and unlisted firms Source: NBS (various years).

\section{Is leveraging supported by economic fundamentals? Evidence from microlevel data}

\section{Changes in important firm characteristics}

After describing the heterogeneous changes in the corporate debt ratio in China, we examine whether these changes are consistent with the changes in the characteristics of the enterprises. Hence, we focus on four key features of enterprises that are commonly tested in the literature on Western capital structure (see Rajan and Zingales 1995; Frank and Goyal 2003), including operational risk (volatility of profit), proportion of tangible assets, profitability and firm scale. Referring to previous research on the capital structure of Chinese enterprises (for example, Wu and Yue 2009), we also examine tax rates and nondebt tax shields. The changes in these six aspects over the period 1998-2013 are reported in Figures 3.14 to 3.19. As these six factors are the major dependent variables in the regressions reported later, we do not report their summary statistics, which have been provided in the figures.

What needs to be explained is as follows.

Our intention in this section is to explore whether changes in debt ratios are consistent with the changes of firm characteristics rather than to set up causal relationships. To demonstrate the causal relationships between various enterprise factors and the debt ratio probably requires exogenous shocks and well-designed identifications. The evidence provided in this chapter is mainly the correlation and therefore is relatively preliminary. Furthermore, our conclusion relies more on the results of the fixed-effects regression in the 'Regression analysis' subsection rather than the descriptive analysis in this subsection. 
The two mainstream capital structure theories_-pecking order theory and trade-off theory-offer different predictions for the relationships between these variables and the debt ratio. We do not elaborate here due to space limitations.

Given a positive or negative relationship between a factor and the debt ratio, different interpretations can be presented based on different theories. In this section, we provide only one explanation, which we consider to be the most intuitive, avoiding more detailed discussions intended to distinguish between different theories, which would take much more space.

Analysing changes in these characteristics is, in itself, important for understanding the overall economic transformation that has taken place in China during this period. However, the focus of this chapter is on discussing whether these changes in time-series are consistent with the change in debt ratios. As for the reasons behind the changes, we offer only speculation that should not be regarded as rigorous analyses or conclusions.

\section{Operational risk}

We first examine the changes in operational risk, measured by the company's standard deviation of the return on assets (ROA) over the past three years. This risk continued to rise after the late 1990s, soaring further in 2008, and then declining slightly (see Figure 3.14). The overall increase in this risk is due in part to the intense competition in China's domestic product market and also because Chinese enterprises are becoming more involved in international market competition. Fierce competition makes it increasingly difficult for an individual enterprise to control the market and maintain a stable profit margin. Fluctuations in profits thereby enhance the uncertainty of future cash flows, which in turn reduce the probability of enterprises being able to obtain external funds. Therefore, the increase in operational risk may be one reason for the overall decline in the debt ratio.

Furthermore, Figure 3.14 also suggests that the less time a company has existed, the greater is the increase in operational risk. For example, the operational risk of enterprises that existed continuously for more than three years rose from 4.9 per cent in 2000 to more than 10 per cent in 2011; however, the risk for firms existing for more than 11 years changed by a much smaller margin. The reason may be that the less time an enterprise exists, the greater is the probability it will be withdrawn from the sample, indicating that the enterprise has a greater risk of bankruptcy and greater probability of default, which also reduces the probability of obtaining external financing. Therefore, Figure 3.14 is consistent with Fact 1, which we observed in Figure 3.6-that is, the less time a firm exists in the sample, the greater is the decline in its debt ratio. 


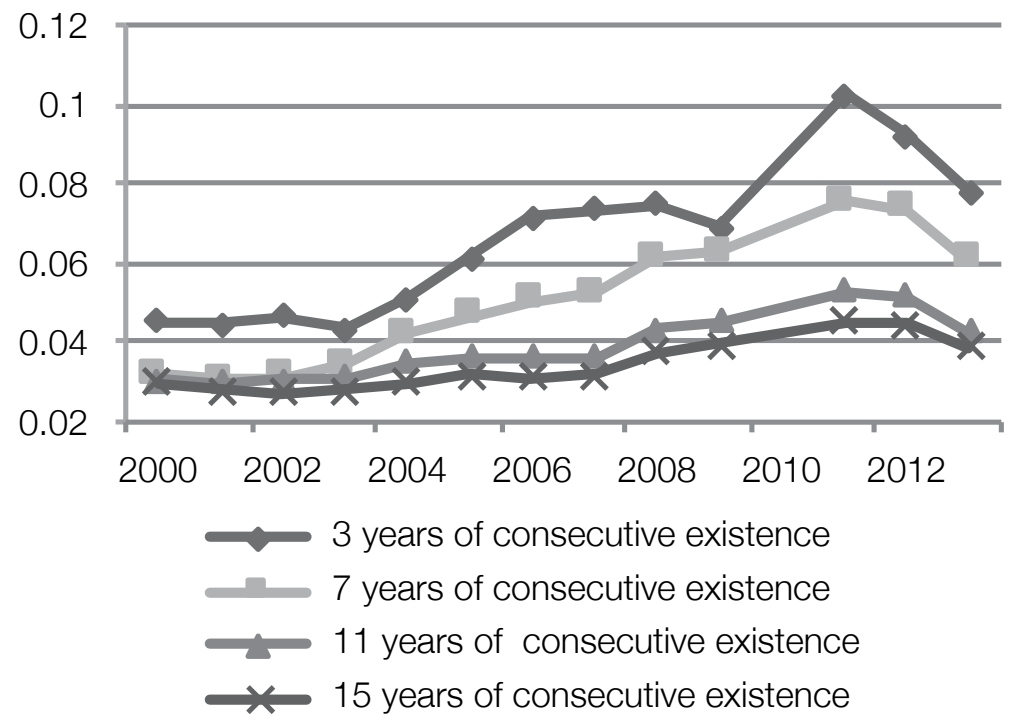

Figure 3.14 Operational risk: Classified by years of consecutive existence Source: NBS (various years).

\section{Proportion of tangible assets}

The proportion of tangible assets-that is, the sum of net fixed assets and net inventories - in the total assets of Chinese enterprises declined from 63 per cent in 1998 to about 48 per cent in 2013, representing a decrease of 15 percentage points in total (see Figure 3.15). The ratio of fixed assets to total assets and the proportion of inventories fell by about 9 and 6 percentage points, respectively.

The decline in the proportion of fixed assets in enterprises is an important manifestation of China's economic transformation, indicating that the mode of firms' production is changing towards greater consistency with their comparative advantages. More specifically, they moved away from a capital-intensive mode during the planned economy period, which violated comparative advantages, to a labourintensive mode (see Lin et al. 1998). The reasons for the decline in inventories are more complicated, possibly due to improvements in logistics or the decline of expected future demand.

Both fixed assets and inventories can be used as collateral for debt financing, so the scale of tangible assets is an important factor in determining the financing ability of an enterprise. The higher the proportion of tangible assets, the lower is the degree of information asymmetry between the enterprises and the banks-thereby, the stronger the borrowing ability a firm has, the easier it will be to obtain debt 
financing. So, the significant decrease in the proportion of tangible assets in Chinese enterprises in the period 1998-2013 is also likely to be an important reason for the overall decline in the debt ratio. ${ }^{13}$

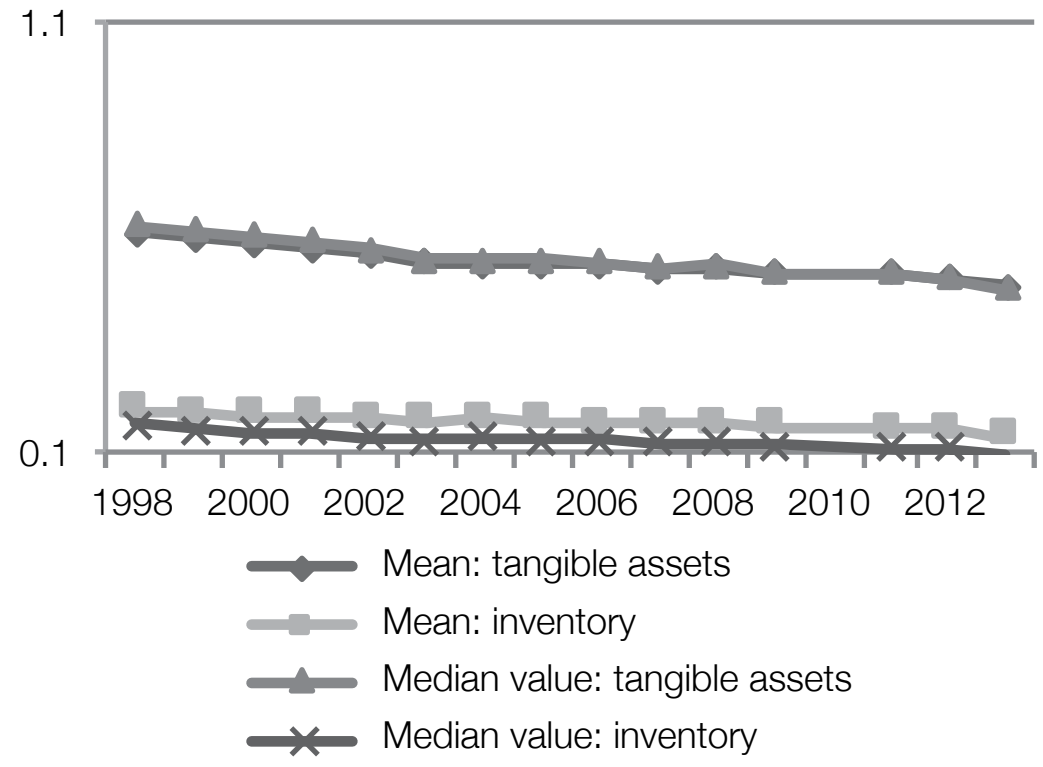

Figure 3.15 The proportion of tangible assets in Chinese enterprises Source: NBS (various years).

\section{Profitability}

Figure 3.16 depicts the sales profit margin - that is, total profit/main business revenue-in four groups of enterprises classified by ownership. The profit margin of all types of enterprises in China continued to rise as a whole and reached a peak by 2011, after which it began to decline slightly. In terms of ownership, the average profit margin of SOEs rose from -1 per cent in 1998 to more than 3 per cent in 2011, whereas that of private enterprises was always the highest among the four categories; it started at less than 3 per cent in 1998 and rose to more than 6 per cent in 2011 .

13 The changes in tangible assets can also explain Fact 3-that the debt ratio of typical heavy industrial enterprises is lower than that of typical light industrial enterprises in Figure 3.6. This may be due to the fact that the proportion of fixed assets of heavy industrial enterprises has declined by a relatively small margin. In addition, Figure 3.3 shows that the decline in the long-term debt ratio is even greater. Compared with short-term liabilities, long-term liabilities require a higher level of collateral. Bhabra et al. (2008) examine the capital structure of Chinese listed companies in different industries and find that capital-intensive firms such as those in manufacturing and utilities have more long-term debt. Therefore, the decline in tangible assets may also be an important reason. 
An increase in the level of profitability means more internal funds, which reduces the need for external financing. Therefore, the continuous rising average profit margin in Chinese enterprises may also be one of the reasons for the overall decline in the debt ratio. Furthermore, the increase in the profit margin of SOEs is most significant among the four groups, which is consistent with the largest drop in their debt ratio, observed in Figure 3.11.

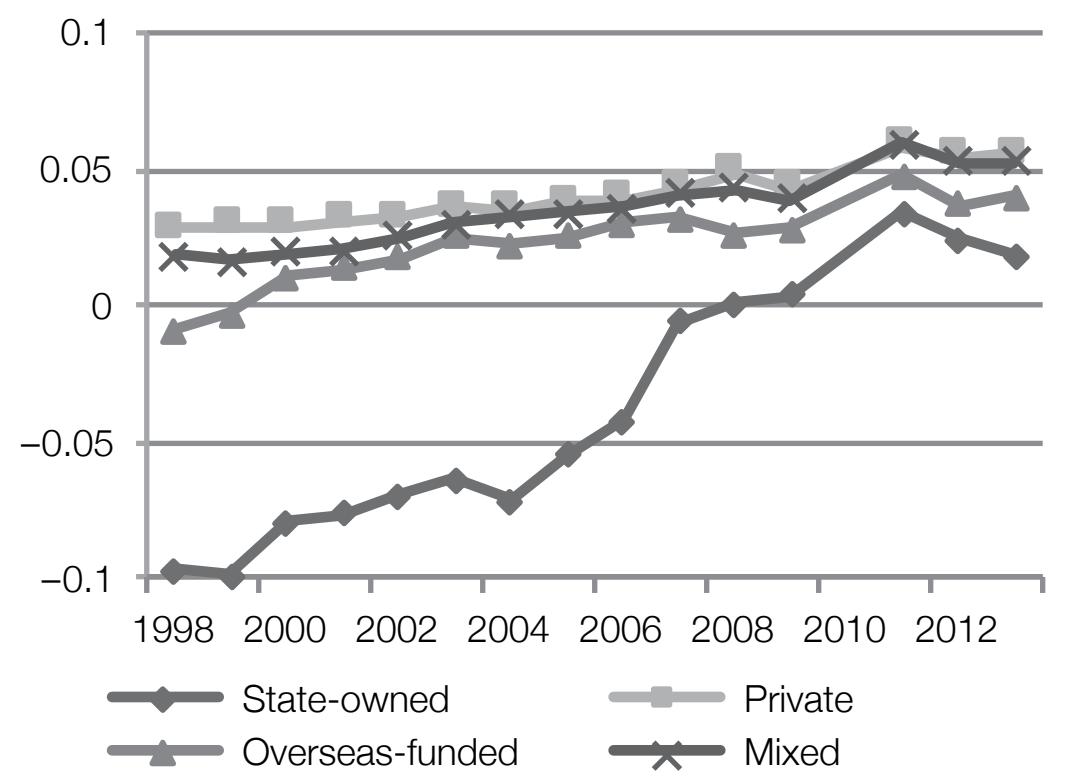

Figure 3.16 Sales profit margin: Enterprises grouped according to ownership Source: NBS (various years).

\section{Size}

Figure 3.17 shows the size of four groups of enterprises, which is measured by the natural logarithm of total assets. The scale of Chinese enterprises as a whole was increasing - in particular, SOEs increased their average size by nearly 20 times from 1998 to 2013. Generally, the larger a company is, the lower is its probability of bankruptcy and the higher is its debt ratio. Therefore, the change in scale does not seem to explain the decline in the overall debt ratio of Chinese enterprises. 


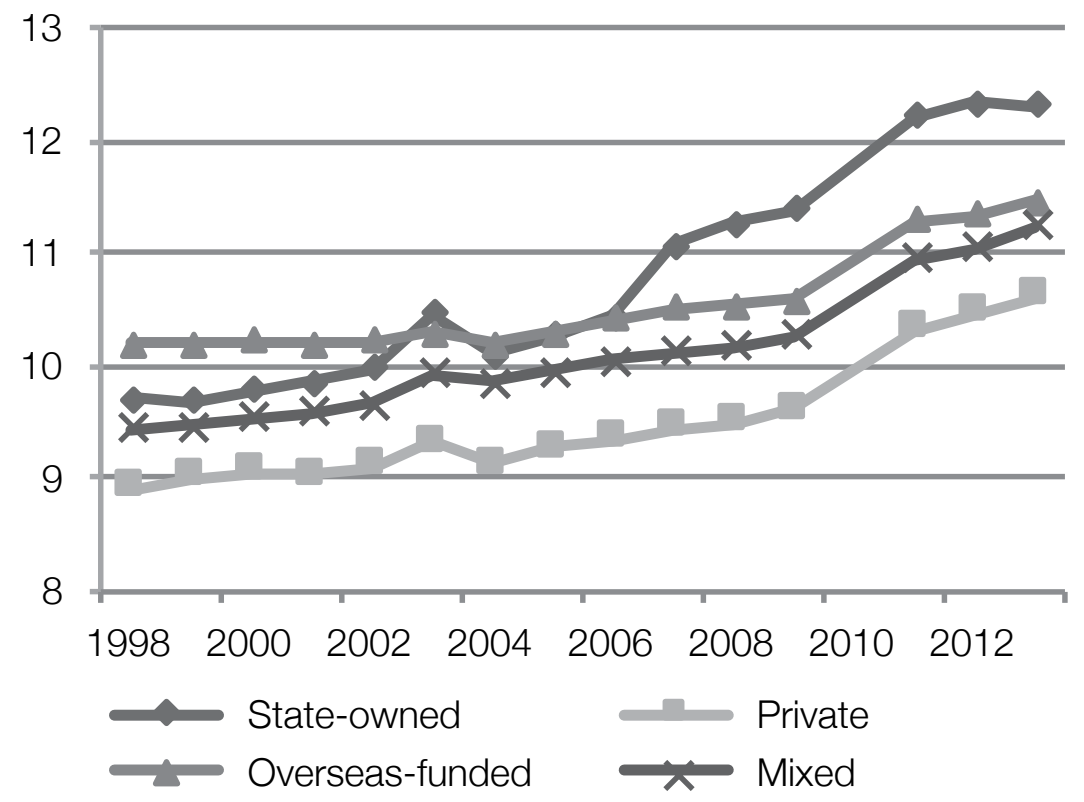

Figure 3.17 Size: Enterprises grouped according to ownership

Source: NBS (various years).

\section{Tax rate}

According to Western literature, the tax rate is an important factor in determining the capital structure of enterprises. Wu and Yue (2009) examine Chinese listed companies and find that change in taxation can lead to a change in the debt ratio. Enterprises should pay interest on debt financing and these expenses reduce their pre-tax profits, thereby reducing income tax. Thus, debt financing can offset part of the tax, which acts as a tax shield, and is the main benefit of debt described by the trade-off theory.

Figure 3.18 displays the income tax rate (income tax payable/total profit) of sample enterprises. ${ }^{14}$ It shows that the average income tax rate of the whole sample rose during the period 1998-2013. At the same time, we also notice that a certain proportion of the sample enterprises have a negative rate. To eliminate the influence of these enterprises, we then calculate the tax rate for those enterprises with a positive level of income tax payable (see Figure 3.18). This shows that the average tax rate for this group of companies stabilised at 27 per cent before 2006, and then decreased sharply in 2007 and 2008, after which it stabilised again, at about 22 per cent.

14 Strictly speaking, the actual income tax rate (income tax expenses/total profit) should be used here. However, this index is not available in the dataset for Chinese industrial firms, so we could only approximate it with the total income tax payable. In addition, income tax expenses include current income tax payable and deferred income tax. 
In short, it shows that there was no significant decrease in the level of tax that could be shielded by debt, so the change in taxation does not appear to be the main reason for the declining debt ratio.

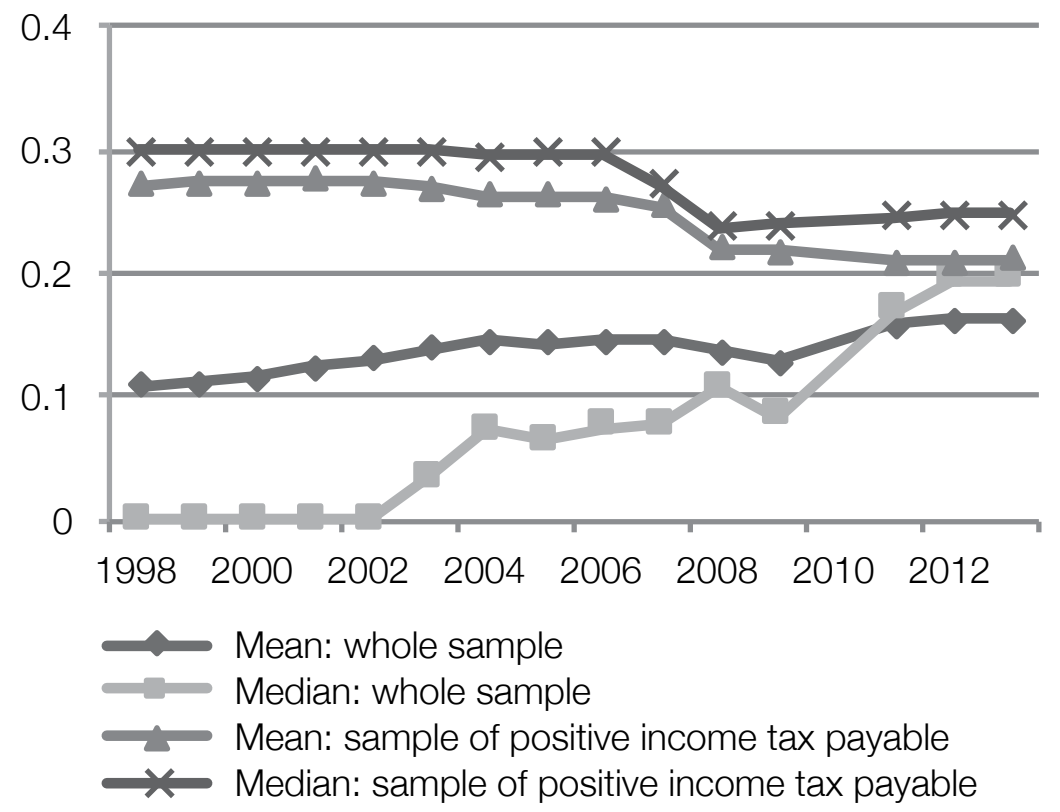

Figure 3.18 Income tax rate of Chinese enterprises

Source: NBS (various years).

\section{Nondebt tax shield}

Like tax shields, depreciation can also reduce the pre-tax profits of an enterprise, thereby reducing the tax payable; hence, it is called a nondebt tax shield, which has a substitute relationship with the debt tax shield and is measured by (depreciation/ main operating revenue). It shows that the nondebt tax shields of the sample enterprises have dropped significantly as a whole (see Figure 3.19), which is consistent with the continuous decline in the proportion of fixed assets that we reported earlier and which should increase the incentive for companies to use debt shields to avoid taxation. According to Figures 3.18 and 3.19, the motivation for Chinese enterprises to use debt to avoid tax expenses has not been reduced, so tax considerations are not the main reason for the sharp decline in the debt ratio of Chinese enterprises. 


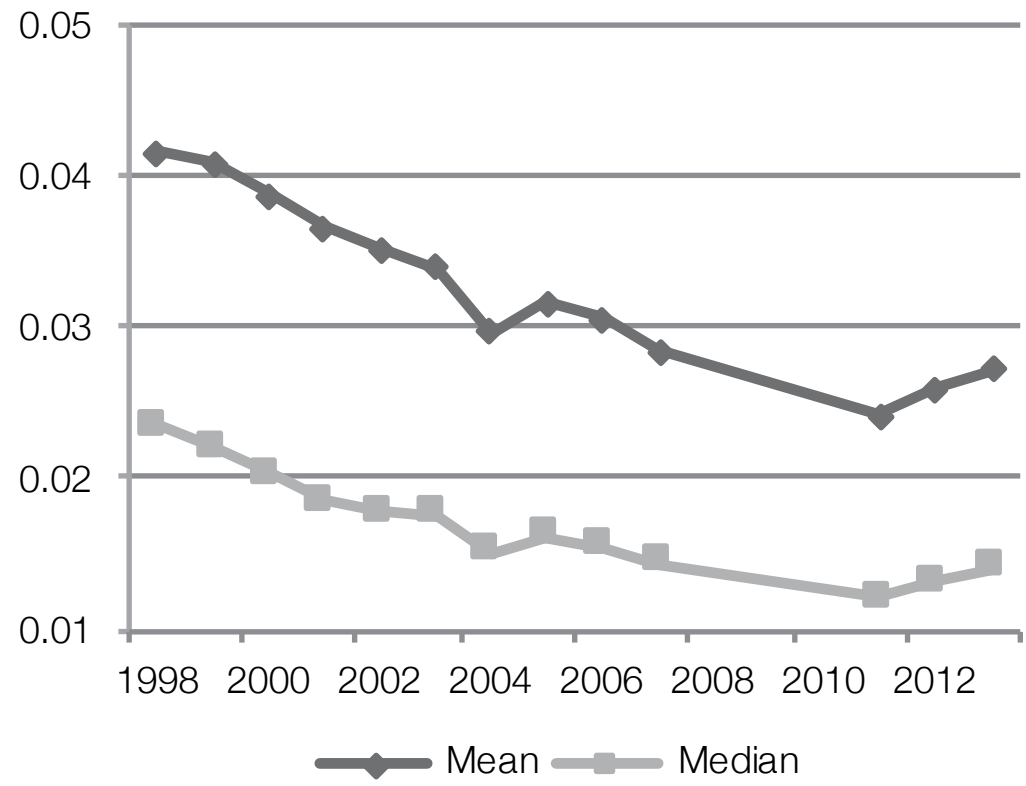

Figure 3.19 Nondebt tax shields of Chinese enterprises

Source: NBS (various years).

\section{Regression analysis: Enterprise characteristics and debt ratio}

Our analyses indicate that the overall decline in Chinese companies' debt ratio may be due in part to the significant changes in the main characteristics of these enterprises, especially their operational risk, profitability and proportion of tangible assets. We use regression analysis to examine more rigorously the relationship between these characteristic variables and the debt ratio.

The explained variable TotLev in Table 3.1 is the debt ratio of each enterprise in the current year. We further control the debt ratio in the previous year (L.TotLev), based on the existence of the 'optimal debt ratio' $\left(\right.$ Levt $\left._{t}^{*}\right)$, which is indicated by the tradeoff theory. It means that if the previous year's debt ratio $\left(\right.$ Levt $\left._{t-1}\right)$ deviates from the optimal one, enterprises will adjust the actual debt ratio $($ Lev $)$ to the optimal level in the current period, which is described by Equation 3.1.

Equation 3.1

$L e v_{t}-\operatorname{Lev}_{t-1}=\lambda\left(\operatorname{Lev}_{t}^{*}-\operatorname{Lev}_{t-1}\right)+\varepsilon_{t}$ 
Table 3.1 Debt ratios of various enterprises in China: Benchmark regression

\begin{tabular}{|c|c|c|c|c|}
\hline & (1) & (2) & (3) & (4) \\
\hline Variables & All & State & Private & Foreign \\
\hline \multirow[t]{2}{*}{ L.TotLev } & $0.269^{\star * \star}$ & $0.365^{\star \star \star}$ & $0.194^{\star \star \star}$ & $0.314^{\star \star \star}$ \\
\hline & $(0.002)$ & $(0.006)$ & $(0.003)$ & $(0.004)$ \\
\hline \multirow[t]{2}{*}{ L.STDROA } & $-0.028^{\star \star \star}$ & 0.017 & $-0.046^{\star \star \star}$ & $0.025^{\star \star}$ \\
\hline & $(0.005)$ & $(0.021)$ & $(0.006)$ & $(0.010)$ \\
\hline \multirow[t]{2}{*}{ L.Size } & $0.003^{\star \star \star}$ & $-0.004^{*}$ & $0.005^{\star \star \star}$ & $0.010^{\star \star \star}$ \\
\hline & $(0.001)$ & $(0.002)$ & $(0.001)$ & $(0.001)$ \\
\hline \multirow[t]{2}{*}{ L.Tng } & $0.010^{\star \star \star}$ & 0.003 & $0.004^{\star *}$ & $0.027^{\star \star \star}$ \\
\hline & $(0.001)$ & $(0.005)$ & $(0.002)$ & $(0.003)$ \\
\hline \multirow[t]{2}{*}{ L.Npr } & $-0.158^{\star \star \star}$ & $-0.088^{\star \star \star}$ & $-0.184^{\star \star \star}$ & $-0.168^{\star \star *}$ \\
\hline & $(0.003)$ & $(0.005)$ & $(0.006)$ & $(0.006)$ \\
\hline \multirow[t]{2}{*}{ L.tax } & $-0.020^{* * *}$ & $-0.028^{\star \star \star}$ & $-0.015^{\star \star \star}$ & $-0.029^{\text {** }}$ \\
\hline & $(0.001)$ & $(0.003)$ & $(0.002)$ & $(0.003)$ \\
\hline \multirow[t]{2}{*}{ Nonpositive*L.tax } & $0.056^{\star \star \star}$ & $0.043^{\star \star \star}$ & $0.065^{\star \star \star}$ & $0.043^{\star \star \star}$ \\
\hline & $(0.004)$ & $(0.008)$ & $(0.006)$ & $(0.010)$ \\
\hline Observations & $1,203,426$ & 159,188 & 675,955 & 288,118 \\
\hline R-squared & 0.825 & 0.879 & 0.821 & 0.818 \\
\hline Number of firm FE & 328,727 & 47,290 & 212,433 & 70,412 \\
\hline Year dummies & YES & YES & YES & YES \\
\hline Province ${ }^{\star}$ Year dummies & YES & YES & YES & YES \\
\hline Industry*Year dummies & YES & YES & YES & YES \\
\hline
\end{tabular}

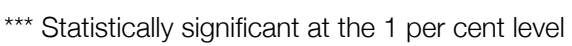

** Statistically significant at the 5 per cent level

* Statistically significant at the 10 per cent level

Note: Standard errors are in parentheses.

Here, $\lambda$ is used to measure the speed of adjustment to the optimal level, depending on the characteristics of the enterprises and the macro situation (see Cook and Tang 2010). A more detailed explanation of this formula can be found in Flannery and Rangan (2006). The econometric model we use is the fixed-effect regression model. Because the debt ratio of the previous period is controlled, there may be a problem of first-order autocorrelation. However, Flannery and Rangan (2006) carefully examine various econometric models and conclude that sequence-related problems are not serious (see p. 479), whereas it is necessary to control the firm fixed effects and the annual dummy variables. Therefore, we refer to their study as well as follow-up ones (including Cook and Tang 2010) and use the ordinary fixed-effect regression model. The number of firm fixed effects controlled by each regression is reported in Table 3.1—for example, 328,727 different enterprises are included in 
the full-sample regression. It is worth noting that because we control the variable $S T D R O A$, the sample firms that are included in the regression should have existed for at least three consecutive years.

We also control a set of dummy variables, including the annual ones (15 in total), (province $\times$ year) (465 in total) and (industry $\times$ year) $(570$ in total). Using these dummy variables and the firm fixed effects, we control not only the effects of certain fixed characteristics of the enterprises (such as the ownership type or political connections) on the debt ratio, but also the regional factors that affect the adjustment of the corporate debt ratio in each province every year (for example, the overall credit situation of each province in that year), as well as industrial factors (for example, the prosperity of each industry in that year). In addition, the set of (industry $\times$ year) being controlled in the regressions equals the average annual debt ratio of each industry being controlled. Frank and Goyal (2009) find that the average debt ratio of an industry has a reliable and stable explanatory power over the corporate debt ratio. By controlling these groups of dummy variables, we try to minimise various endogenous issues between enterprise characteristics and the debt ratio. Firm characteristics are lagged by one period to reduce the reverse causalities between these variables and the debt ratio. Because of the control of these firm characteristics and many dummy variables, the $R^{2}$ of the regressions are all above 80 per cent.

The results using the full sample are reported in Column (1), while Columns (2), (3) and (4) report the results using the subsample of state-owned, private and foreignfunded enterprises, respectively. ${ }^{15}$ Our findings are as follows: 1) the coefficient of L. TotLev is $(1-\lambda)$, which means that the adjustment speed of private enterprises $(1-0.194)$ is higher than that of SOEs $(1-0.365) ; 2)$ the variable of STDROA is the standard deviation of ROA over the past three years, which is significantly negative in both the full sample and private enterprises, whereas it is not significant in the sample of SOEs; 3) Size is measured by the logarithm of total assets and is significantly positive in the full sample and for private enterprises, while being negative in the sample of SOEs (significance at the 10 per cent level); 4) as for the proportion of tangible assets to the total assets, $T n g$ is significantly positive in the full sample and for private enterprises, but not significant in the sample of SOEs; 5) $N p r$ represents the sales profit margin and is negative in all sets of samples, while its magnitude in the private enterprises sample is more than twice the effect for SOEs.

In sum, in the private sector, the relationships between these four variables and the debt ratio are consistent with the findings in the Western literature. The results in Columns (1) - (4) indicate that the financing decisions in Chinese private enterprises

15 There is also a type of enterprise with mixed ownership; because of the unclear ownership and space limitations, we do not report the relative results. 
are more in line with those made by Western companies - in other words, they are more market-oriented. Nevertheless, only the result for the sales profit margin coincides with the Western empirical findings in the sample of Chinese SOEs.

In addition to these four factors, we divide the sample into two groups according to whether the enterprise's income tax payable is positive in the previous period. Thus, one group includes those enterprises with a positive tax rate (nonpositive $=0$ ) and the other includes those with a negative rate (nonpositive $=1$ ). In the group with a positive tax rate, the variable of L. Tax that represents the tax rate in the previous period is negatively correlated with the debt ratio, and the negative effect in the sample of SOEs is even greater. In the other group, because the tax rate itself is nonpositive and the estimated value of L.Tax is positive, the actual effect is also negative. Briefly stated, for Chinese enterprises, the higher the income tax rate in the previous period, the lower is the debt ratio in the later period. This seems to indicate that Chinese industrial enterprises do not deliberately add liabilities to reduce taxation, which is contrary to the conclusions obtained from the existing literature examining China's listed companies, including Huang and Song (2006) and Wu and Yue (2009). This issue is worth studying more carefully.

Through this analysis, we draw a preliminary conclusion that the financing decisions of some enterprises - most of which are private enterprises-are in accordance with the principle of marketisation. Meanwhile, the financing decisions of other enterprises_-most of which are SOEs_contain many nonmarket factors. The financing behaviours of these enterprises lack support from the economic fundamentals. In other words, these firms have borrowed too much, which is not ideal because they must carry a high interest burden.

We have also examined Chinese listed companies to provide further evidence supporting our conclusions. According to our calculations, in 2015, there were more than 160 listed SOEs that did not have enough profits to cover their interest expenses (see Figure 3.20). What is worse, these enterprises had to borrow more money to repay the capital and interest; as a result, more and more debt is accumulated. We found that, from 2010 to 2015, the total liabilities of these 160 enterprises rose from RMB980 billion (US $\$ 145$ billion) to RMB1.68 trillion (US $\$ 270$ billion). In other words, the 160 enterprises in deficit borrowed RMB700 billion (US $\$ 130$ billion) in additional debt during this period. This also means the debt ratio of these enterprises is so high that it leads to heavy interest burdens. It is worth noting that our estimates are consistent with the estimates made in 2016 by Wang and Zhong (2016) — that the proportion of nonfinancial companies listed on the main stock market board that had lower earnings before interest and tax than interest expenses was 11.7 per cent in the first half of 2015. This means that 160 to 200 large Chinese listed firms, most of which are state-owned, did not have enough profit to pay their interest. 


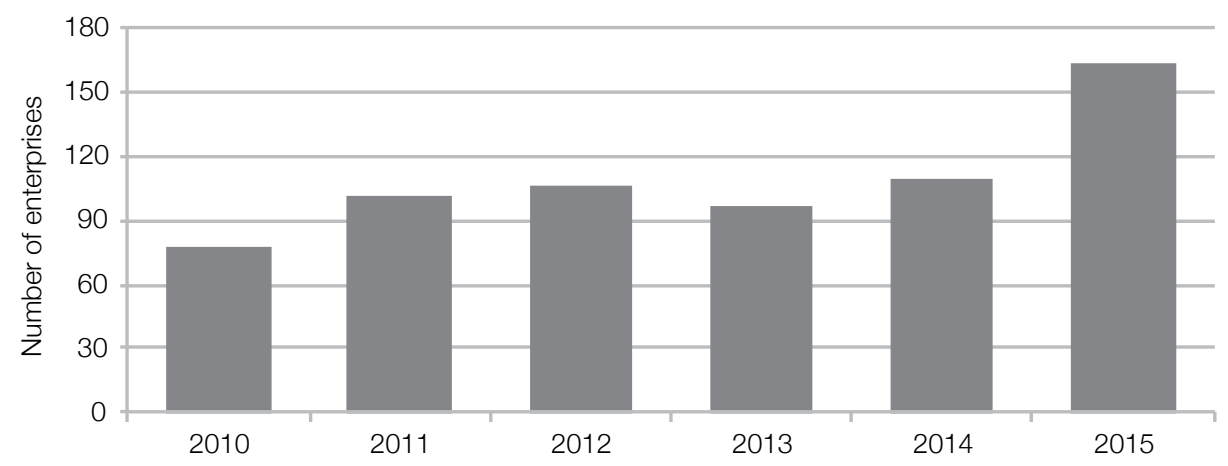

Figure 3.20 SOEs with heavy interest burdens

Source: CSMAR and authors' calculation.

\section{Is leveraging supported by economic fundamentals? Evidence from aggregate-level data}

In this section, we provide more evidence regarding who should be deleveraging and who should be leveraging. As shown in Figure 3.21, the state-owned sector as a whole continuously increased its leverage after 2008, as its average debt ratio rose from 59 per cent in 2008 to 62 per cent by 2016. Moreover, the total debt of the state-owned sector continues to rise. According to data released by the Ministry of Finance, by November 2017, the total liabilities of the Chinese stateowned sector reached RMB100 trillion (US\$15.1 trillion). Among them, the total liabilities of the central SOEs were RMB51.5 trillion (US\$7.8 trillion)—soaring by nearly 9.6 per cent compared with a year earlier-while those of local SOEs were RMB48.5 trillion (US\$7.3 trillion), contributing to 12.3 per cent of year-on-year growth. The private sector has been deleveraging sharply, with the average debt ratio of private industrial enterprises falling from 56 per cent in 2008 to 50.7 per cent in 2016 (see Figure 3.21). In other words, the private sector has been deleveraging for more than a decade. 


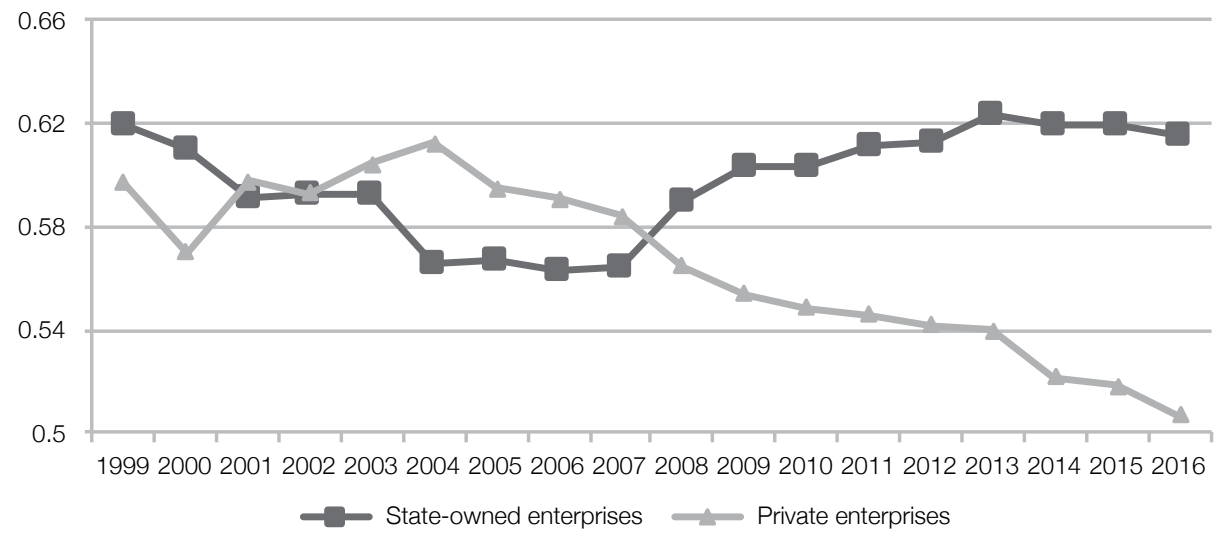

Figure 3.21 The average debt ratio: State-owned versus private enterprises Source: NBS.

On the other hand, until recently, private industrial enterprises contributed nearly 40 per cent of the total profit of all industrial enterprises, whereas their liabilities accounted for only 20 per cent of the total (see Figure 3.22). This means that the financial resources used by the private sector are far below their economic contribution. In contrast, SOEs contributed less than 20 per cent of the total profit of all industrial enterprises, while their liabilities accounted for more than 40 per cent of the total.

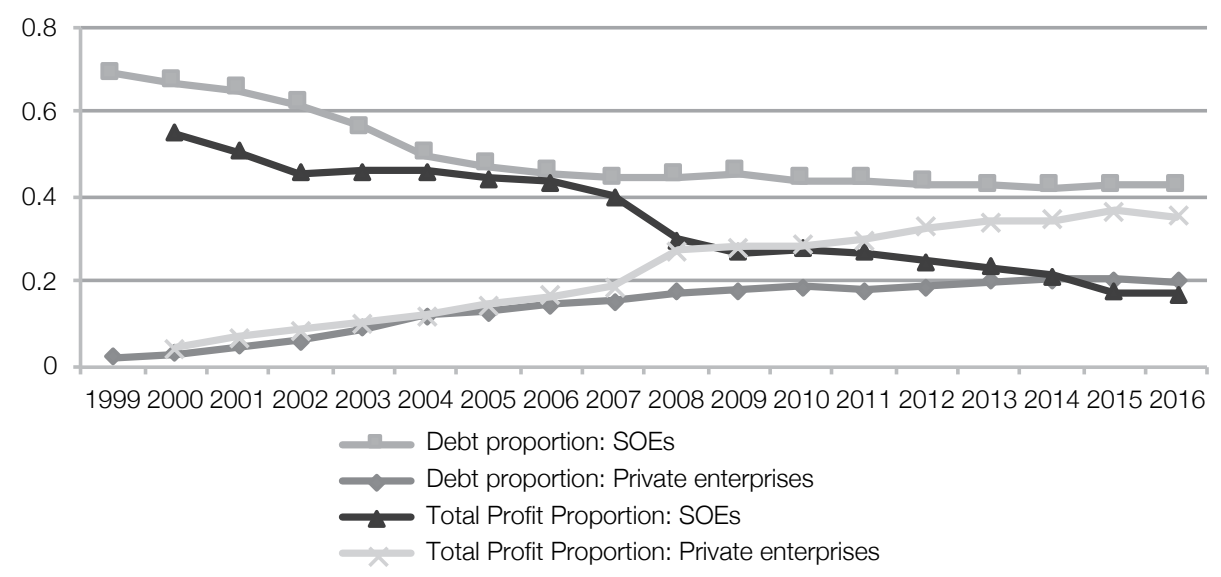

Figure 3.22 The contrast in total profit: State-owned versus private enterprises Source: NBS.

It is worth mentioning that this gap between financial support and economic contribution is consistent with another important phenomenon arising after the GFC - that is, SOEs widely participated in various kinds of shadow banking activities. For example, using the data on entrusted loans published by the Shanghai 
Stock Exchange and the Shenzhen Stock Exchange, Zhang et al. (2015) estimate that SOEs made 75 per cent of entrusted loans in 2013. This means these firms did not have good investment opportunities themselves but borrowed a substantial amount of money at a low cost from the financial system and then made loans to those companies that could not borrow from the formal financial system, at higher interest-rate-to-gain margins. Moreover, according to reports in the Financial Times on 16 August 2016, large Chinese SOEs were increasingly involved in entrusted loans when facing a downturn in their core business. The total stock of China's entrusted loans reached RMB12 trillion (US\$1.8 trillion) in June 2016, increasing by 70 per cent since early 2014. In addition, entrusted loans became the fastest growing area of China's shadow banking industry. All these data prove that Chinese SOEs have borrowed too much money. Their debt ratio is too high and greatly beyond their ability to repay.

Therefore, to improve the efficiency of credit allocation, the first thing we should do is overcome the 'polarity' in financing activities between the state-owned and private sectors dating from 2008, so that the financial support to and economic contribution of the various sectors is roughly equal.

\section{Conclusions and policy discussions}

Recently, the demographic dividend that drove China's rapid economic growth over the past decades has been rapidly exhausted. Because of the family planning policies that began in the early 1980s, China's population will age rapidly in the next few years. If China wants to maintain high-speed economic growth in the ensuing period, it should first rely on the optimal allocation of capital, encouraging the efficient use of machinery and equipment, to increase the marginal output of the existing labour force. Second, China should rely on continuous innovation to move closer to the global technological frontier. To realise these two goals, the efficient allocation of resources in China's financial system is crucial. More specifically, can finance be allocated to enterprises with high efficiency and real productivity and to those early projects with innovative potential to support their development?

As mentioned at the beginning of this chapter, after 2008, the efficiency of credit in China declined significantly. One important reason for this is that those inefficient enterprises are receiving large amounts of funds. This constrains investment and innovation in the healthy and efficient enterprises and inhibits new enterprises from entering the industry. Furthermore, the phenomenon of 'finance does not support entities' has become more serious and, ultimately, has led to the inefficiency of the economy. 
On the other hand, China's overall debt ratio has been rising continually; as a result, the pressure for deleveraging is increasing. Should the economy be deleveraged and, if so, how should we do it? Based on analysis of a dataset containing nearly 4 million above-scale Chinese industrial enterprises during the period 1998-2013, we attempted to provide some preliminary evidence to answer these questions. We focused on the following two issues.

First, the overall debt ratio of nonfinancial enterprises in China is at a high level, but where is the leveraging exactly? We find that most industrial enterprises were significantly deleveraged during the 16-year period, while only a small number of large, state-owned and listed enterprises increased their leveraging. Second, is the change in the debt ratio supported by the economic fundamentals? For this question, we first examine the changes in some key characteristics of the sample enterprises and find that the overall decline in the debt ratio is consistent with significant changes in certain characteristics, including an increase in operational risk and profitability, as well as a decline in the proportion of tangible assets. We further find in the regression analysis that the determination of the debt ratio in private enterprises basically accords with the findings in the Western literature; in contrast, SOEs are including fewer 'market-oriented' factors in their financial decision-making.

As for whether to deleverage and how to deleverage in China, our research is still preliminary. Nevertheless, the results and analysis in this chapter indicate that a complete answer should include at least two parts. First, for enterprises whose financial decision-making is consistent with the principle of marketisation (mainly private enterprises), sufficient capital supply should be ensured so the economic fundamentals support these enterprises obtaining adequate funds. Second, as for another group of enterprises, whose leveraging determinants contain more 'nonmarket' factors (mainly SOEs), funding 'transfusions' for such inefficient objects should be suspended, so that new loans can be allocated to the most efficient enterprises. Based on these results, we also have two specific suggestions for real implementation.

First, China's high rate of leveraging is a structural issue, with a large amount of debt concentrated in a few enterprises. In this case, a general and unified monetary policy - whether it is tight or loose — can be inefficient, and may even increase the severity of existing mismatches. The problem is not whether monetary policy should be loosened or tightened; rather, the transmission of monetary policy in China's financial system is seriously biased: credits are not allocated to those 'healthy' enterprises that need capital urgently. Therefore, effective policies must gradually correct the inefficiency of existing financial intermediaries, especially the allocation of funds in the banking system, and weaken the power of non-marketisation. 
Second, for those SOEs that are inefficient and in deficit, debt is a 'stock', but new loans are 'flows', which should not be used to solve the stock problem. Paying off old debts with new loans can only lead to a rapid accumulation of total liabilities. According to the estimations from Wang and Zhong (2016), in 2015, between RMB1.5 trillion (US $\$ 240$ billion) and RMB2 trillion (US\$320 billion) of total new debt was used to repay previous interest expenses, which is equivalent to around 10 per cent of total new credit in that year. We suggest the problem of debt as stock should be settled by, for example, selling a portion of state-owned assets to repay debt, while restructuring the enterprises in deficit to enhance their capability.

For those enterprises with negative net assets, in particular, shutting down, suspending, merging or transforming them will increase the value of total stateowned assets rather than devaluing them. The point of selling assets is, in fact, to identify opportunities in the market to make full use of these assets. If these assets can be fully utilised, it will benefit the entire economy. With the current high debt ratio in China, new credit is a particularly valuable resource that needs to be used wisely and cautiously. Moreover, the allocation efficiency of incremental credits is directly related to China's medium and long-term potential economic growth.

To summarise, the high levels of leveraging in China are a structural issue that require 'structural' policies to be resolved. On the one hand, deleveraging is not right for most enterprises, but it is for inefficient areas, especially a few thousand highly leveraged firms. The main battlefield for deleveraging is the state-owned sector, especially inefficient and large enterprises, which usually have severe overcapacity. Thus, the Chinese Government should promote market-oriented reform of SOEs as well as a policy of 'shutting down, suspending, merging and transforming' firms to realise the goal of 'distinct property rights, well-defined power and responsibility, separation of government and enterprises, and scientific management', as proposed by the Third Plenary Session of the Fourteenth Central Committee more than two decades ago.

On the other hand, it is equally important to increase leveraging in efficient areas; efficient private enterprises should receive more support via new credit. For that, market-oriented reform of commercial banks and other financial intermediaries in China needs to be promoted further, so that valuable credit resources can be allocated to those enterprises with real productivity and sufficient returns on capital. In sum, the core aim of deleveraging is to keep deepening the reform of the state-owned sector so that new power and vitality can be generated for China's economic growth. 


\section{References}

Bhabra, H.S., Liu, T. and Tirtiroglu, D. (2008), Capital structure choice in a nascent market: Evidence from listed firms in China, Financial Management 37(2): 341-64. doi.org/10.1111/j.1755-053X.2008.00015.x.

Caballero, R.J., Hoshi, T. and Kashyap, A.K. (2008), Zombie lending and depressed restructuring in Japan, American Economic Review 98(5): 1943-77. doi.org/10.1257/ aer.98.5.1943.

Caixin (2016), Huang Yiping: Cracking down on China's high-leverage trap, Caixin, 14 March.

Chen, J.J. (2004), Determinants of capital structure of Chinese listed companies, Journal of Business Research 57(12): 1341-51. doi.org/10.1016/S0148-2963(03)00070-5.

Chen, J. and Strange, R. (2005), The determinants of capital structure: Evidence from Chinese listed companies, Economic Change and Restructuring 38(1): 11-35. doi.org/ 10.1007/s10644-005-4521-7.

China Business Journal (2011), The 'Inside Job' of banks in China, and shadow banking prevails, China Business Journal Online, available from: www.cb.com.cn/deep/2011_ 0910/271245_2.html.

China News (2012), Li Yang: Liabilities of Chinese enterprises have exceeded the warning line, China News, 18 May.

Cook, D.O. and Tang, T. (2010), Macroeconomic conditions and capital structure adjustment speed, Journal of Corporate Finance 16(1): 73-87. doi.org/10.1016/ j.jcorpfin.2009.02.003.

Financial Times (2016), Large Chinese enterprises seeking higher returns from entrusted loans, Financial Times, 16 August, available from: www.ftchinese.com/story/001068932.

Flannery, M.J. and Rangan, K.P. (2006), Partial adjustment toward target capital structures, Journal of Financial Economics 79(3): 469-506. doi.org/10.1016/j.jfineco.2005.03.004.

Frank, M.Z. and Goyal, V.K. (2009), Capital structure decisions: Which factors are reliably important?, Financial Management 38(1): 1-37. doi.org/10.1111/j.1755-053X. 2009.01026.x.

Frank, M.Z. and Goyal, V.K. (2003), Testing the pecking order theory of capital structure, Journal of Financial Economics 67(2): 217-48. doi.org/10.1016/S0304405X(02)00252-0.

Huang, G. and Song, F.M. (2006), The determinants of capital structure: Evidence from China, China Economic Review 17(1): 14-36. doi.org/10.1016/j.chieco.2005.02.007. 
Li, K., Yue, H. and Zhao, L. (2009), Ownership, institutions, and capital structure: Evidence from China, Journal of Comparative Economics 37(3): 471-90. doi.org/10.1016/j.jce. 2009.07.001.

Lin, J.Y., Cai, F. and Li, Z. (1998), Competition, policy burdens, and state-owned enterprise reform, American Economic Review 88(2): 422-27.

National Bureau of Statistics of China (NBS) (various years), Annual Survey of Industrial Enterprises, Beijing: China Statistics Press.

Newman, A., Gunessee, S. and Hilton, B. (2012), Applicability of financial theories of capital structure to the Chinese cultural context: A study of privately owned SMEs, International Small Business Journal 30(1): 65-83. doi.org/10.1177/0266242610370977.

Rajan, R.G. and Zingales, L. (1995), What do we know about capital structure? Some evidence from international data, Journal of Finance 50(5): 1421-60. doi.org/10.1111/ j.1540-6261.1995.tb05184.x.

Sina Finance (2017), Li Yang's view on de-leveraging: Monetary policy will be tight, Sina Finance, 23 September.

Sohu Finance and Economics (2017), Is it true that China's total debt exceeds 200 trillion and is ranked second worldwide?, Sohu Finance and Economics, 18 February.

Standard \& Poor's (2014), Credit shift: As global corporate borrowers seek $\$ 60$ trillion, Asia-Pacific debt will overtake US and Europe combined, RatingsDirect, June.

Tan, Y., Huang, Y. and Woo, W.T. (2016), Zombie firms and the crowding-out of private investment in China, Asian Economic Papers 15(3): 32-55. doi.org/10.1162/ ASEP_a_00474.

Wang, T. and Zhong, J. (2016), What are the real problems with China's debt?, UBS Global Research, April.

Wu, L. and Yue, H. (2009), Corporate tax, capital structure, and the accessibility of bank loans: Evidence from China, Journal of Banking \& Finance 33(1): 30-8. doi.org/ 10.1016/j.jbankfin.2006.10.030.

Zhang, W., Han, G., Ng, B. and Chan, S. (2015), Corporate leverage in China: Why has it increased fast in recent years and where do the risks lie?, HKIMR Working Paper No. 10/2015, Hong Kong: Hong Kong Institute for Monetary Research. doi.org/10.2139/ ssrn. 2597451. 
This text is taken from The Chinese Economic Transformation: Views from Young Economists, edited by Ligang Song, Yixiao Zhou and Luke Hurst, published 2019 by ANU Press, The Australian National University, Canberra, Australia.

doi.org/10.22459/CET.2019.03 